\title{
MENGKAJI EFEKTIVITAS PENGGUNAAN ARIMA DAN VAR DALAM MELAKUKAN PROYEKSI PERMINTAAN UANG KARTAL DI INDONESIA
}

\begin{abstract}
Untoro $^{1}$
A bstraksi

Kajian ini dilakukan untuk mendapatkan model yang dapat memproyeksikan posisi uang kartal di masyarakat. Dengan data bulanan pendekatan $\operatorname{ARIMA}(12,1,13)$ mampu memproyeksikan posisi uang kartal hingga 12 periode kedepan dengan tingkat deviasi sebesar 2,6\%, atau lebih baik dibanding dengan pendekatan model VAR yang mempergunakan variabel uang kartal, net foreign asset (NFA), kredit perbankan, nilai tukar, indeks harga saham gabungan, dan cadangan devisa (reserve). Hasil dengan modeIVAR memberikan deviasi proyeksi 5,2\% (model VAR tanpa ADD factor) dan 6,5\% (model VAR dengan $A D D$ factor). Dengan deviasi yang rendah tersebut maka modelARIMA(12,1,13) dapat dipergunakan oleh pihak otoritas moneter dalam kebijakan pemenuhan kebutuhan uang kartal masyarakat.
\end{abstract}

Keywords: uang kartal, ARIMA, VAR, proyeksi

JEL Classification: C32, E41

1 Peneliti Madya pada Pusat Pendidikan dan Studi Kebanksentralan (PPSK) - Bank Indonesia 


\section{PENDAHULUAN}

\section{I.1. Latar Belakang}

Uang memiliki peranan strategis dalam perekonomian terutama karena fungsi utamanya sebagai media untuk bertransaksi, sehingga pada awalnya sering diartikan bahwa uang adalah sesuatu yang dapat diterima umum sebagai alat pembayaran. Namun sejalan dengan perkembangan perekonomian, fungsi uang yang semula hanya sebagai alat pembayaran berkembang menjadi alat satuan hitung dan sebagai alat penyimpan kekayaan.

Mengingat pentingnya keberadaan uang dalam perekonomian, maka penyediaan jumlah uang kartal dimasyarakat harus sesuai dengan jumlah yang dibutuhkannya. Jumlah uang kartal yang berlebihan akan mendorong masyarakat pemegang uang kartal tersebut untuk membelanjakannya atau mendorong masyarakat melakukan tindakan spekulasi dengan menukarkan jumlah uang kartal yang dimiliki kepada uang kertas asing. Akibatnya akan menimbulkan inflasi dan penurunan nilai tukar rupiah. Ketepatan dalam melakukan proyeksi uang kartal secara tepat di masyarakat akan membantu Bank Indonesia, sebagai otoritas yang memiliki wewenang mencetak dan mengedarkan uang, dalam melakukan perencanaan pencetakan dan distribusi uang kartal rupiah di Indonesia

Kajian permintaan uang di Indonesia telah dilakukan oleh empat peneliti yaitu masingmasing dilakukan oleh Bijan B. Aghevli (1976), Boediono (1985), Price Simon dan Insukindro (1994), dan Triatmo Doriyanto (1999). Masing-masing dengan menggunakan pendekatan yang berbeda dan akan diulas dalam bab dua pada tulisan ini.

Dengan memperhatikan hal-hal tersebut diatas dan dengan mendasarkan pada fungsi uang, yaitu tidak saja sebagai alat pembayaran tetapi juga sebagai media penyimpan dan sebagai dasar penghitungan berbagai transaksi ekonomi dan keuangan, maka kajian mengenai proyeksi permintaan uang kartal dilakukan. Dengan kajian ini diharapkan dapat memberikan sumbangan pada Bank Indonesia dalam kebijakan penyediaan uang kartal di masyarakat.

\section{I.2. Rumusan Masalah Penelitian}

Terdapat beberapa pendekatan yang dapat dilakukan dalam melakukan proyeksi uang kartal di masyarakat. Dalam penelitian ini penulis membatasi diri pada pendekatan ARIMA dan Vector Autoregression (VAR). Pembandingan ini dilakukan untuk melihat ketepatan proyeksi dengan hanya mengekplorasi pada data yang bersangkutan (pendekatan ARIMA) dan dengan memanfaatkan beberapa varibel yang dapat digunakan untuk membantu dalam melakukan proyeksi uang kartal (pendekatan VAR). Oleh karena itu permasalahan penelitian yang dapat dikemukakan adalah : 
- Memperoleh model ARIMA yang sesuai untuk dapat melakukan proyeksi uang kartal di masyarakat.

- Memperoleh model VAR yang sesui untuk dapat melakukan proyeksi uang kartal di masyarakat

- Melakukan perbandingan efektifitas proyeksi uang kartal antara metode ARIMA dan metode VAR

\section{I.3. Tujuan Penelitian}

Tujuan dari penelitian ini adalah mendapatkan model penghitungan jumlah uang kartal yang sesuai yang dapat memproyeksikan jumlah uang kartal di masyarakat beberapa periode kedepan. Hasil proyeksi yang mendekati angka aktualnya akan membantu pihak otoritas moneter dalam melakukan kebijakan penyediaan uang kartal (bank note) secara tepat sesuai dengan kebutuhan likuiditas perekonomian.

\section{TINJAUAN TEORITIS DAN EMPIRIS}

\section{II.1. Tinjauan Teoritis}

Teori yang membahas mengenai permintaan akan uang telah berkembangan seiring dengan perkembangan permintaan akan uang dan fungsi akan uang itu sendiri. Salah satu teori klasik yang mengupas mengenai permintaan uang adalah teori kuantitas uang, atau The Quantity Theory of Money. Teori ini membahas permintaan dan sekaligus penawaran akan uang beserta interaksi antara keduanya yang berfokus pada hubungan antara penawaran uang (jumlah uang beredar) dengan nilai uang (tingkat harga).

$$
\mathrm{MV}_{\mathrm{T}}=\mathrm{PT}
$$

$\mathrm{V}_{\mathrm{T}}$, transaction velocity of circulation, adalah variabel yang ditentukan oleh kelembagaan yang ada di dalam masyarakat, dan dalam jangka pendek dapat dianggap konstan. T, volume transaksi, dalam suatu periode teretentu ditentukan oleh tingkat pendapatan nasional ataupun output masyarakat.

$$
\mathrm{M}_{\mathrm{d}}=\frac{1}{\mathrm{~V}_{\mathrm{T}}} \mathrm{PT}
$$

Dengan demikian permintaan akan uang masyarakat adalah sesuatu proporsi tertentu $\frac{1}{\overline{\mathrm{V}}_{\mathrm{t}}}$ dari nilai transaksi ( $\mathrm{P} \overline{\mathrm{T}}$ ). Tanda (“-“) menunjukan variabel-variabel yang dianggap konstan dalam jangka pendek. Dengan kondisi keseimbangan $\left(\mathrm{M}_{\mathrm{d}}=\mathrm{M}_{\mathrm{s}}\right)$ maka akan diperoleh persamaan 


$$
\mathrm{M}_{\mathrm{s}}=\frac{1}{\overline{\mathrm{V}}_{\mathrm{T}}} \mathrm{P} \overline{\mathrm{T}}
$$

Dalam jangka pendek tingkat harga umum (P) berubah secara proporsional dengan perubahan uang yang diedarkan pemerintah. Dalam teori ini $\overline{\mathrm{T}}$ ditentukan oleh tingkat output ekuilibrium masyarakat (oleh Fisher dan ahli ekonomi klasik disebut full employment, hukum Say atau Say's Law).

Fisher menyatakan bahwa permintaan uang akan timbul dari penggunaan uang dalam proses transaksi, dimana tiap perekonomian sesuai tahapan pertumbuhannya memiliki sistem kelembagaan tersendiri yang menentukan sifat proses transaksi tersebut. Sistem kelembagaan ini mencakup beberapa faktor, misalnya tingkat "monetisasi" sektor-sektor ekonomi, kredit perdagangan, perbaikan dalam komunikasi, dan sistem jaringan perbankan. Proses transaksi yang berlaku di masyarakat dalam suatu periode inilah yang kemudian menentukan besar kecilnya $\overline{\mathrm{V}}_{\mathrm{T}}$, transaction velocity of circulation. Faktor kelembagaan akan mengalami perubahan secara gradual dalam jangka panjang, sedangkan dalam jangka pendek kebutuhan akan uang relatif terhadap volume transaksi bisa dianggap konstan. Demikian pula volume transaksi relatif terhadap output masyarakat bisa dianggap mempunyai proporsi yang konstan dalam jangka pendek.

Seperti halnya teori Fisher dan teori-teori klasik lainnya, Teori Cambridge (Marshall-Pigou), berpokok pangkal pada fungsi uang sebagai alat tukar umum (means of exchange). Oleh karena itu, teori-teori klasik ini melihat permintaan uang dari masyarakat sebagai kebutuhan akan alat likuid untuk tujuan transaksi. Perbedaan utama dari teori Cambridge dan Fisher ini terletak pada teori Fisher berfokus pada permintaan uang yang semata-mata merupakan proporsi konstan dari volume transaksi yang dipengaruhi oleh faktor-faktor kelembagaan yang konstan. Sedangkan teori cambridge lebih menekankan faktor-faktor perilaku (pertimbangan untung rugi) yang menghubungkan antara permintaan uang seseorang dengan volume transaksi yang direncanakannya.

Secara garis besar, permintaan uang menurut teori Cambridge ini selain dipengaruhi oleh volume transaksi dan faktor-faktor kelembagaan, juga dipengaruhi oleh bunga, dan ramalan / ekspektasi masyarakat terhadap kondisi masa yang akan datang. Faktor-faktor yang mempengaruhi permintaan uang seseorang dengan demikian juga akan mempengaruhi permintaan uang masyarakat secara keseluruhan. Yang selanjutnya Pigou melakukan berbagai penyederhanaan dimana variabel-variabel yang mempengaruhi permintaan uang, dalam jangka pendek dianggap konstan atau hanya dimasukan kedalam analisa teori uang mereka secara kualitatif. 
Teori Cambridge menganggap bahwa ceteris paribus permintaan uang adalah proporsional dengan tingkat pendapatan nasional. Dengan demikian persamaan permintaan uang adalah

$$
\mathrm{M}_{\mathrm{d}}=\mathrm{k} \mathrm{P} \overline{\mathrm{Y}}
$$

Dimana $\overline{\mathrm{Y}}$ adalah pendapatan nasional riil. Suplai uang $\left(\mathrm{M}_{\mathrm{S}}\right)$ ditentukan oleh pemerintah. Dalam kondisi keseimbangan maka:

$$
\mathrm{M}_{\mathrm{s}}=\mathrm{kP} \overline{\mathrm{Y}}
$$

Atau:

$\mathrm{P}=\frac{1}{\mathrm{k}} \mathrm{M}_{\mathrm{s}} \overline{\mathrm{Y}}$

Jadi ceteris paribus pada tingkat harga umum (P) berubah secara proporsional dengan perubahan volume uang yang beredar. Perbedaan teori Cambridge dibandingkan teori fisher dalam hal ceteris paribus (faktor-faktor lain seperti pendapatan nasional riil, tingkat bunga dan ekspektasi konstan) dinilai cukup penting, karena dengan demikian teori Cambridge tidak menutup kemungkinan bahwa faktor-faktor seperti tingkat bunga dan ekspektasi berubah walaupun dalam jangka pendek (dengan berubahnya faktor-faktor ini maka "k" pun akan berubah).

Teori uang dari Keynes adalah bagian dari teori ekonomi makro yang dituangkan dalam bukunya General Theory. Meskipun bisa dikatakan bahwa teori uang Keynes bersumber dari teori Cambridge, tapi Keynes mengemukakan sesuatu yang berbeda dalam teorinya dibandingkan teori-teori klasik. Perbedaan ini terutama berasal dari penekanan Keynes mengenai fungsi uang yang lain, yaitu sebagai store of value bukan hanya sebagai means of exchange. Teori inilah yang kemudian dikenal dengan sebutan Liquidity Preference.

Dalam teorinya, Keynes masih sependapat dengan pemikiran Cambridge, dimana orang memegang uang untuk melancarkan proses transaksi yang dilakukan, dan permintaan uang masyarakat untuk tujuan ini dipengaruhi oleh tingkat pendapatan nasional dan tingkat bunga. Semakin besar tingkat pendapatan nasional, semakin besar tingkat transaksi, maka semakin besar pula jumlah uang yang diminta masyarakat untuk transaksi. Keynes juga berpendapat bahwa permintaan uang untuk transaksi inipun bukan merupakan suatu proporsi yang konstan, tapi juga dipengaruhi oleh tinggi rendahnya tingkat bunga. Hanya saja faktor bunga dalam permintaan uang untuk transaksi ini tidak terlalu ditekankan. Salah satu sebabnya adalah karena ia ingin menekankan permintaan uang untuk tujuan lain, yaitu tujuan spekulasi.

Motif memegang uang untuk tujuan spekulasi terutama ditujukan untuk mendapatkan keuntungan. Pada garis besarnya Keynes membatasi keadaan dimana pemilik kekayaan bisa 
memilih memegang kekayaannya dalam bentuk tunai atau obligasi. Uang tunai dianggap tidak memberikan penghasilan, sedang obligasi dianggap memberikan penghasilan berupa sejumlah uang tertentu setiap periodenya.

Dalam teori Keynes ini dibicarakan secara khusus obligasi yang memberikan suatu penghasilan berupa sejumlah uang tertentu dalam setiap periode selama waktu yang tidak terbatas (perpetuity). Secara umum bisa ditulis dengan persamaan sebagai berikut:

$$
\mathrm{K}=\mathrm{R} \mathrm{P}
$$

Dimana $\mathrm{K}$ adalah hasil per tahun yang diterima, $\mathrm{R}$ adalah tingkat bunga, dan $\mathrm{P}$ adalah harga pasar dari obligasi "perpetuity" tersebut. Persamaan tersebut bisa pula ditulis sebagai berikut:

$$
\mathrm{P}=\frac{\mathrm{K}}{\mathrm{R}}
$$

Persamaan tersebut menunjukan bahwa harga pasar obligasi berbanding terbalik dengan tingkat bunga (dengan " $\mathrm{K}$ " konstan). Bila tingkat bunga turun maka harga pasar obligasi akan naik, begitupula sebaliknya.

Atas dasar hal diatas maka bentuk yang sederhaana dari permintaan akan uang Keynes adalah:

$$
\frac{\mathrm{M}_{\mathrm{d}}}{\mathrm{P}}=[k \mathrm{Y}+\Phi(\mathrm{R} \mathrm{W})]
$$

Dimana $\frac{\mathrm{M}_{\mathrm{d}}}{\mathrm{P}}$ adalah permintaan total dari uang dalam bentuk riil, $k \mathrm{Y}$ adalah permintaan uang untuk transaksi atau berjaga-jaga, yang dinyatakan sebagai bentuk proporsi (k) dari pendapatan nasional riil. Sedangkan $\Phi(\mathrm{RW})$ adalah permintaan uang uantuk motif spekulasi yang dinyatakan sebagai fungsi dari tingkat bunga yang berlaku (R) dan nilai riil dari aset (kekayaan) yang dipegang masyarakat (W). Variabel W ini dimasukan karena permintaan uang untuk motif spekulasi dinyatakan sebagai bagian dari W yang dipegang dalam bentuk tunai. Persamaan diatas dapat pula dinyatakan dalam bentuk permintaan uang dalam satua moneter seperti dibawah ini.

$$
\mathrm{M}_{\mathrm{d}}=[k \mathrm{Y}+\Phi(\mathrm{R}, \mathrm{W})] \mathrm{P}
$$

Dalam menganalisa jangka pendek W biasanya dianggap konstan sehingga menjadi:

$$
\mathrm{M}_{\mathrm{d}}=[k \mathrm{Y}+\Phi(\mathrm{R})] \mathrm{P}
$$

Dimana $\Phi(\mathrm{R})=\Phi(\mathrm{R} W)$. Dan dalam posisi ekuilibrium, suplai uang $\left(\mathrm{M}_{\mathrm{s}}\right)$, yang juga dianggap oleh keynes sebagai variabel yang ditentukan oleh pemerintah, sama dengan $\mathrm{M}_{\mathrm{d}^{\prime}}$ sehingga: 
$\mathrm{M}_{\mathrm{s}}=[k \mathrm{Y}+\Phi(\mathrm{R})] \mathrm{P}$

Perbedaan antara teori Klasik dengan teori dari Keynes adalah dalam teori Keynes menekankan bahwa pasar uang $\left(\mathrm{M}_{\mathrm{d}}, \mathrm{M}_{\mathrm{s}}\right)$ terutama menentukan tingkat bunga, sedangkan teori klasik menekankan bahwa pasar uang terutama menentukan tingkat harga. Menurut Keynes tingkat harga $(\mathrm{P})$ tidak selalu ditentukan oleh permintaan dan penawaran uang, tapi ditentukan sebagai resultante dari permintaan dan penawaran agregat.

Dalam model Keynes yang paling sederhana, $\mathrm{P}$ bahkan dianggap konstan untuk tingkat output berada dibawah full employment, dan akan berubah secara kurang lebih proporsional dengan suplai uang pada tingkat output full employment. Model keynesian yang lebih kompleks memasukan kemungkinan harga-harga naik sebelum titik full employment tercapai dan juga kenaikan harga yang tidak proporsional dengan kenaikan suplai uang.

Pelopor pembaharuan teori kuantitas (klasik) sesudah Keynes adalah Profesor Milton Friedman dari University of Chicago. Teori kuantitas modern dari Friedman ini adalah pengembangan lebih lanjut dari teori Cambridge, yaitu bahwa teori permintaan uang hanyalah suatu penerapan dari teori umum mengenai permintaan dalam ekonomi mikro, sedang prinsip dasarnya adalah sama yaitu pemilihan antara berbagai alternatif oleh konsumen (dalam permintaan uang adalah pemilik kekayaan).

Sejalan dengan teori konsumen, dalam teori permintaan uangnya, Friedman menganggap bahwa pemilik kekayaan memutuskan aktiva-aktiva apa yang akan dipegang atas dasar perbandingan manfaat, selera dan jumlah kekayaannya. Pengertian kekayaan dari Friedman tidak hanya berbentuk uang atau bisa diubah atau dijual menjadi uang, tetapi juga termasuk nilai dari aliran penghasilan di tahun-tahun mendatang dari tenaga kerjanya. Kekayaan tidak lain adalah nilai sekarang dari aliran penghasilan yang diharapkan dari aktiva-aktiva yang dipegang. ${ }^{2}$ Pengertian kedua yang penting adalah "manfaat". Manfaat (returns) dari setiap bentuk aktiva merupakan faktor pertimbangan untuk memutuskan berapa jumlah dari masingmasing bentuk aktiva yang akan dipegang tersebut.

Dalam melakukan perumusan fungsi permintaan uang (permintaan total uang, Friedman tidak mengenal pembagian motif memegang uang seperti Keynes), Friedman melakukan beberapa penyederhanaan. la menganggap pemilik kekayaan bisa memilih lima bentuk kekayaan untuk dipegang, yaitu: Uang tunai (M), obligasi (B), saham atau equities (E), barang-barang fisik bukan manusia (G), dan kekayaan manusiawi / human capital (H). 2 Friedman tidak menekankan pengertian historis dari kekayaan, tapi justru pada arti ekonomis dari konsep kekayaan, terutama
kaitannya dengan potensinya sebagai penghasil pendapatan (atau Utility) di masa datang. 
Dalam bentuk persamaan, maka permintaan akan uang tunai seseorang individu adalah:

$$
M=f\left\lfloor W, P, R,\left(R-\frac{d R / d t}{R}\right),\left(R-\frac{d R / d t}{R}+\frac{d P / d t}{P}\right) \frac{d P / d t}{P}, K, u\right\rfloor
$$

Jumlah aktiva yang akan dipegang dalam bentuk uang tunai (M) ditentukan oleh:

1. Besarnya kekayaan yang dimiliki (W). Semakin besar kekayaan maka akan semakin banyak uang tunai yang dibutuhkan oleh orang tersebut.

2. Perbandingan antara return dari berbagai macam aktiva yang dipegang.

3. Rasio antara kekayaan manusiawi dan kekayaan bukan manusiawi (K). semakin besar $\mathrm{K}$ makan akan semakin besar uang tunai yang diminta.

4. Selera

Perkembangan teori Keynes mengenai permintaan uang yang khusus membahas mengenai permintaan untuk transaksi berpangkal pada karya Profesor William Baumol dari Universitas Princeton (1952) dan Profesor James Tobin dari Universitas Yale (1956). Baumol dan Tobin mencapai kesimpulan yang serupa mengenai permintaan uang untuk transaksi. Baumol melihat bahwa kebutuhan akan uang untuk transaksi pada hakekatnya adalah sama dengan kebutuhan stok (dalam hal ini stok uang) yang akan dipegang dengan pertimbangan biaya dengan memilih jumlah dan pola waktu untuk stok yang tepat agar biaya yang membebaninya minimal.

Model Baumol ini bertitik tolak dari anggapan bahwa seseorang menerima pendapatan tertentu secara reguler setiap waktu, dan untuk penyederhanaan orang tersebut selalu membelanjakan sejumlah tertentu (tetap) setiap harinya. Dengan kata lain kebutuhan uang tunai per satuan waktu adalah konstan. Pemilik pendapatan tersebut juga dapat memilih memegang hasil pendapatannya dalam bentuk uang tunai atau obligasi.

Uang tunai dianggap tidak menghasilkan apapun, tapi dipegang karena bisa digunakan untuk transaksi. Sedangkan obligasi menghasilkan tingkat bunga, tapi bila ingin digunakan untuk transaksi harus terlebih dahulu ditukarkan kedalam bentuk uang tunai. Selanjutnya dianggap bahwa setiap kali menjual obligasi, ada biaya (tetap) yang dibebankan. Biaya ini sebesar $\mathrm{b}$, nilai riil dari pendapatannya sebesar $\mathrm{T}$, tingkat bunga per periode $\mathrm{R}$, sedangkan $\mathrm{K}$ adalah nilai obligasi yang akan dijual dengan tujuan memenuhi kebutuhan uang tunai untuk transaksi dalam jangka waktu tertentu. Karena uang tunai tidak menghasilkan apapun, maka orang akan cenderung memegang pendapatan totalnya sebanyak mungkin dalam bentuk obligasi. Keputusan ini dilakukan dengan mempertimbangkan biaya yang paling menguntungkan. Biaya total dari pemegangan stok ini adalah: 


$$
\mathrm{C}=\mathrm{b} \frac{\mathrm{T}}{\mathrm{K}}+\mathrm{R} \frac{\mathrm{K}}{2}
$$

Variabel b adalah biaya tetap setiap kali ia melakukan penjualan obligasi, sedang T/K adalah berapa kali dalam periode penghasilannya ia akan menjual obligasi. Jadi bT/K adalah seluruh biaya penjualan obligasi selama periode penghasilannya. K adalah jumlah obligasi yang dijual tiap kalinya, atau dengan kata lain $\mathrm{K}$ adalah jumlah stok awal dari uang tunai yang setiap kalinya akan ia pegang untuk memenuhi kebutuhan transaksi.

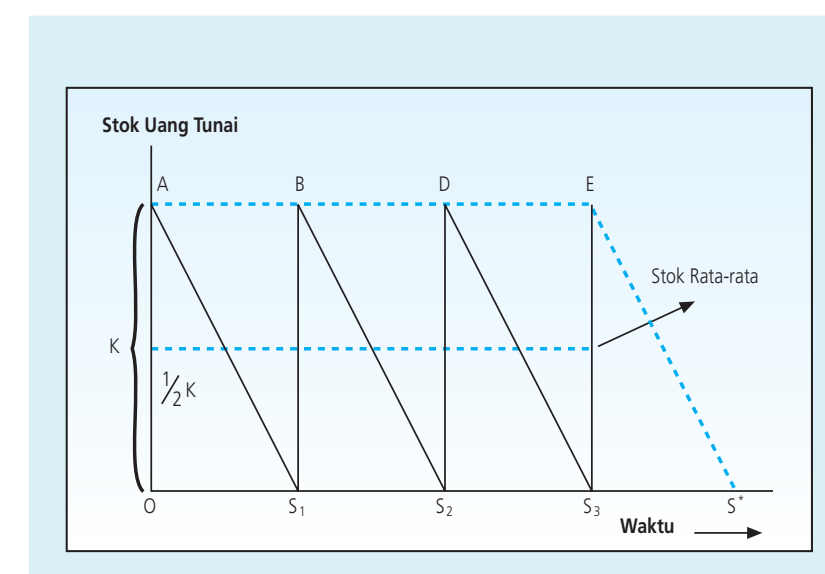

Gambar IV.1.

Dimana OS* adalah periode penghasilan, dan selama periode tersebut ia memperoleh penghasilan sebesar $\mathrm{T}$. sejumlah uang tunai tertentu $(\mathrm{K})$ dipegang pada awal tiap periode pembelanjaan (nilai K sama untuk tiap awal periode $\mathrm{O} \rightarrow \mathrm{S}, \mathrm{S}_{1} \rightarrow \mathrm{S}_{2}, \mathrm{~S}_{2} \rightarrow \mathrm{S}_{3}$ ). Pada waktu $\mathrm{O}$ ia mendapatkan stok uang tunai sebesar $\mathrm{K}$, yang dipakai dengan tingkat penggunaan konstan tiap harinya selama $\mathrm{O} \rightarrow \mathrm{S}_{1}$ (garis lurus $\mathrm{A} \rightarrow \mathrm{S}_{1}$ ). Pada saat mencapai $\mathrm{S}_{1}$ stok uangnya habis, kemudian ia menjual stok obligasinya sehingga stok uang tunainya kembali menjadi $\mathrm{K}$, yang kemudian digunakan untuk transaksi dengan pola yang sama, demikian seterusnya sampai periode $\mathrm{S}_{3}$ biaya penjualan obligasi selama periode OS* adalah sebesar bT/K. Sedang biaya berupa kehilangan bunga adalah sebesar tingkat bunga, $\mathrm{R}$, dikalikan stok rata-rata selama periode tersebut. Jadi biaya bunga yang ia tanggung selama periode tersebut adalah RK/2. Dengan demikian biaya totalnya didapatkan sebesar $\mathrm{C}$ pada persamaan diatas.

Untuk memilih $\mathrm{K}$ yang meminimumkan $\mathrm{C}$ didapatkan dengan menurunkan fungsi $\mathrm{C}$ terhadap $\mathrm{K}$ dan menyamakannya dengan nol. 


$$
\frac{\partial \mathrm{C}}{\partial \mathrm{K}}=-\frac{\mathrm{bT}}{\mathrm{K}^{2}}+\frac{\mathrm{R}}{2}=0
$$

Atau:

$$
\mathrm{K}=\sqrt{\frac{2 \mathrm{bT}}{\mathrm{R}}}
$$

Kalau b, R, dan $\mathrm{T}$ kita ketahui nilainya maka $\mathrm{K}$ akan bisa didapatkan. $\mathrm{K}$ dalam persamaan tersebut adalah stok awal uang tunai yang optimal.

Dari persamaan ini kita bisa memperoleh fungsi permintaan uang tunai untuk tujuan transaksi. Jumlah uang tunai yang dibutuhkan setiap waktu tidak lain adalah stok rata-rata yang ia pegang atau $=\mathrm{K} / 2$. Jadi permintaan uang untuk transaksi adalah:

$$
\frac{\mathrm{M}_{\mathrm{d}}}{\mathrm{P}}=\frac{\mathrm{K}}{2}=\frac{1}{2} \sqrt{\frac{2 \mathrm{bT}}{\mathrm{R}}}
$$

Perhatikan bahwa permintaan akan uang tunai disini adalah permintaan uang tunai dalam arti riil yaitu dengan anggapan tingkat harga konstan. Permintaan uang tunai untuk transaksi dalam satuan uang (in money terms) bisa didapatkan dengan memindahkan variabel $\mathrm{P}$ ke sisi kanan dari persamaan.

$$
\mathrm{M}_{\mathrm{d}}=\left(\frac{1}{2} \sqrt{\frac{2 \mathrm{bT}}{\mathrm{R}}}\right) \mathrm{P}
$$

atau

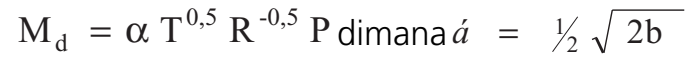

Fungsi permintaan akan uang tunai untuk transaksi pada persamaan jelas berbeda dengan fungsi permintaan uang Keynes. Bila benar setiap masyarakat menentukan permintaannya akan uang tunai untuk tujuan transaksi seperti apa yang digambarkan oleh Baumol, maka fungsi permintaannya menunjukan adanya economies of scale dari penggunaan uang. Bisa dilihat bila pendapatan totalnya (T) naik, misalnya 2 kali lipat, maka permintaan uangnya naik 20,5 atau 1,414 kali, berarti ada penghematan (economies) dari kebutuhan uang relatif terhadap pendapatan. Berbeda dengan bentuk proporsional $\mathbf{M}_{d}=\mathrm{kYP}$, dimana peningkatan $\mathrm{Y} 2$ kali lipat akan meningkatkan permintaan uang 2 kali lipat juga. Adanya economies of scale ini memiliki konsekuensi lanjut, yaitu permintaan masyarakat akan uang untuk transaksi tidak hanya bergantung pada pendapatan nasional (Y), tapi juga pada distribusi pendapatan. Apabila sebagian besar Y diterima oleh sebagian kecil orang, maka permintaan uang masyarakat akan lebih kecil dibandingkan distribusi pendapatan lebih merata. 
Dalam kondisi full employment yaitu dimana pendapatan riil tidak bisa naik lagi, maka kenaikan Ms akan menyebabkan kenaikan P (bukan lagi kenaikan Y) secara proporsional (meskipun ada economies of scale). Efek seperti ini juga dijumpai dalam keadaan dimana tidak ada economies of scale :

$$
\begin{aligned}
& \mathrm{M}_{\mathrm{s}} \rightarrow 2 \mathrm{M}_{\mathrm{s}} \\
& 2 \mathrm{M}_{\mathrm{s}}=2 \mathrm{M}_{\mathrm{d}} \\
& 2 \mathrm{M}_{\mathrm{d}}=(\mathrm{T})^{0,5} \mathrm{R}^{0,5}(2 \mathrm{P})
\end{aligned}
$$

Dalam kasus proporsional (tidak ada economies of scale

$$
\begin{aligned}
& \mathrm{M}_{\mathrm{d}}=\mathrm{kYP} \\
& 2 \mathrm{M}_{\mathrm{d}}=\mathrm{kY}(2 \mathrm{P})
\end{aligned}
$$

( $\overline{\mathrm{T}}$ dan $\bar{Y}$ adalah "full employment income" )

\section{II.2. Tinjauan Empiris}

Dalam tinjauan empiris dikaji empat penelitian yang masing-masing dilakukan oleh Bijan B. Aghevli, Boediono, Price Simon dan Insukindro, dan Triatmo Doriyanto. Keempat penelitian tersebut mengambil kasus permintaan uang di Indonesia dengan menggunakan pendekatan ekonometrik.

Penelitian yang dilakukan oleh Bijan B. Aghevli (1976) mencoba melihat hubungan antara uang dan tingkat harga dengan menggunakan alat analisis model ekonometrik dari sektor moneter. Penelitian yang dilakukan ditujukan untuk menyediakan estimasi besarnya ekspansi moneter yang sesuai agar konsisten dengan target pertumbuhan pendapaatan riil dan tingkat harga.

Permintaan real balance, (M/P)*, biasanya adalah fungsi keseimbangan dari pendapatan riil, $Y$, dan tingkat inflasi, $\pi$, yang mengukur biaya opportunitas memegang uang relatif terhadap barang.

$\log (M / P)^{*}=a_{0}+a_{1} \log (Y)+a_{2} \pi \quad a_{1}>0 ; a_{2}<0$

Persamaan diatas menggambarkan permintaan total dari keseluruhan Liquidity. Koefisien $\mathrm{a}_{1}$ adalah long-run income elasticity sedangkan $\mathrm{a}_{2}$ adalah koefisien dari inflasi.

$$
\begin{array}{ll}
\log (\mathrm{D} / \mathrm{C})^{*}=\mathrm{d}_{0}+\mathrm{d}_{1} \log (\mathrm{Y})+\mathrm{a}_{2} & \mathrm{~d}_{1}>0 \\
\log (\mathrm{T} / \mathrm{D})^{*}=\mathrm{e}_{0}+\mathrm{e}_{1} \log (\mathrm{Y})+\mathrm{e}_{2} \log (\mathrm{r}) & \mathrm{e}_{1}, \mathrm{e}_{2}>0
\end{array}
$$


Ketiga persamaan diatas menggambarkan permintaan portofolio yang diinginkan masyarakat dalam bentuk berbagai komponen dari uang. Diasumsikan masyarakat menyesuaikan bentuk aset moneter riil yang dipegangnya kedalam tingkatan yang diinginkannya, dimana masyarakat menambah simpanan asetnya sebesar $\lambda$ yang merupakan selisih antara permintaan yang diinginkan dengan suplai aktual dari periode sebelumnya. Sehingga didapatkan:

$$
\Delta \log (\mathrm{M} / \mathrm{P})_{\mathrm{t}}=\lambda\left[\log (\mathrm{M} / \mathrm{P})^{*}{ }_{\mathrm{t}}-\log (\mathrm{M} / \mathrm{P})_{\mathrm{t}-1}\right]+\mathrm{a}_{2} \pi \quad 0<\lambda<1
$$

Persamaan diatas menggambarkan partial adjustment mechanism dari real balance (M/ P). Dan dengan mensubstitusikan didapatkan:

$$
\log (\mathrm{M} / \mathrm{P})_{\mathrm{t}}=\mathrm{a}_{0} \lambda+\mathrm{a}_{1} \lambda \log (\mathrm{Y})_{\mathrm{t}}+\mathrm{a}_{2 \mathrm{t}} \lambda \pi_{\mathrm{t}}+(1-\lambda) \log (\mathrm{M} / \mathrm{P})_{\mathrm{t}-1}
$$

Dengan mengasumsikan masyarakat menyesuaikan rasio demand deposit terhadap currency, dan uang kuasi terhadap demand deposit, kedalam tingkat yang diinginkan menurut partial adjustment mechanism, maka permintaan terhadap riil balance dapat diturunkan kedalam persamaan:

$$
\begin{aligned}
& \log (\mathrm{D} / \mathrm{C})_{\mathrm{t}}=\mathrm{d}_{0} \Phi+\mathrm{d}_{1} \Phi \log (\mathrm{Y})_{\mathrm{t}}+(1-\Phi) \log (\mathrm{D} / \mathrm{C})_{\mathrm{t}-1} \\
& \text { dan } \\
& \log (\mathrm{T} / \mathrm{D})_{\mathrm{t}}=\mathrm{e}_{0} \gamma+\mathrm{e}_{1} \gamma \log (\mathrm{Y})_{\mathrm{t}}+\mathrm{e}_{2} \gamma \log (\mathrm{r})_{\mathrm{t}}+(1-\gamma) \log (\mathrm{T} / \mathrm{D})_{\mathrm{t}-1}
\end{aligned}
$$

Dimana, $\Phi$ dan $\gamma$ menggambarkan koefisien partial adjustment dari (D/C) dan (T/D). Sementara itu, suplai uang nominal ditentukan oleh berubahan dari cadangan uang (reserve money) dan pengganda uang. Dalam kerangka pemikiran ini, peningkatan dari cadangan uang akan menghasilkan peningkatan dari suplai likuiditas seiring bank meningkatkan jumlah kreditnya dengan penambahan cadangan tersebut. Dengan cadangan uang dinotasikan sebagai RM, currency, C, dan reserve yang dipegang oleh sektor perbankan, $\mathrm{R}$ maka didapat:

$$
\mathrm{RM} \equiv \mathrm{C}+\mathrm{R}
$$

Hasil estimasi dengan menggunakan estimasi persamaan simultan dengan metode twostage least-square, adalah sebagi berikut:

$$
\begin{aligned}
& \log (\mathrm{M} / \mathrm{P})_{\mathrm{t}}=-0,213+0,486 \log (\mathrm{Y})_{\mathrm{t}}-0,798 \pi_{\mathrm{t}}+0,788 \log (\mathrm{M} / \mathrm{P})_{\mathrm{t}-1} \\
& \begin{array}{ccc}
(0,188) & (0,211) \quad(0,133) & (0,059)
\end{array} \\
& \mathrm{R}^{2}=0,99 \\
& \log (\mathrm{D} / \mathrm{C})_{\mathrm{t}}=-0,390+0,460 \log (\mathrm{Y})_{\mathrm{t}}+0,410 \log (\mathrm{D} / \mathrm{C})_{\mathrm{t}-1}
\end{aligned}
$$

$$
(0,122) \quad(0,144) \quad(0,170)
$$




$$
\begin{aligned}
& \mathrm{R}^{2}=0,85 \\
& \log (\mathrm{T} / \mathrm{D})_{\mathrm{t}}=-0,740+0,410 \log (\mathrm{Y})_{\mathrm{t}}+0,190 \log (\mathrm{r})_{\mathrm{t}}+0,810 \log (\mathrm{T} / \mathrm{D})_{\mathrm{t}-1}
\end{aligned}
$$

$$
(0,285) \quad(0,256) \quad(0,066) \quad(0,065)
$$

$\mathrm{R}^{2}=0,97$

Hasil simulasi tersebut mengindikasikan hubungan dari ketiga persamaan tersebut cukup stabil. Hal ini dibuktikan dengan melihat nilai dari $\mathrm{R}^{2}$ yang cukup tinggi dan koefisien dari seluruh parameternya signifikan secara statistik.

Penelitian yang dilakukan oleh Boediono (1985) mencoba untuk mengidentifikasikan faktor-faktor penentu dari permintaan uang di Indonesia selama periode 1975 - 1984. Kajian yang dilakukan mencakup uang kartal (currency), narrow money (M1) dan broad money (M2). Kerangka kerja yang digunakan mengadopsi pada pendekatan yang selama ini berkembang, dimana faktor yang mempengaruhi permintaan uang masyarakat adalah gross domestic product (GDP), suku bunga dalam negeri (umumnya digunakan suku bunga deposito), dan inflasi domestic, serta dengan memperhitungkan karakteristik dari perekonomian Indonesia, seperti keterbukaan pada sektor perdagangan dan finansialnya terhadap kondisi perekonomian internasional. Variabel GDP merupakan terkait dengan motif permintaan uang untuk transaksi. Tingkat bunga menggambarkan biaya memegang uang dalam hubungannya dengan tabungan dalam bentuk jumlah uang yang tidak dapat diperoleh bila tetap memegang uang dalam bentuk tunai sebesar bunga yang dibayarkan. Inflasi menunjukan biaya dalam dalam hubungannya dengan barang dalam bentuk menurunnya nilai uang terhadap barang ketika inflasi terjadi. Dengan memasukkan pengaruh keterbukaan dalam model permintaan uang dalam perekonomian, maka dapat memasukkan dampak peningkatan return dari aset luar negeri terhadap penurunan uang yang dipegang masyarakat. Aset luar negeri dimaksud adalah berupa aset-aset finansial, terutama deposito berjangka. Tingkat pengembalian dari investasi ini adalah tingkat bunga yang berlaku di pasar uang internasional. Peningkatan yang terjadi di dalam tingkat bunga internasional akan menurunkan tingkat uang domestik yang dipegang masyarakat.

Variabel-variabel lain yang dijadikan sebagai penentu permintaan uang antara lain: a) Gross Domestic Income (GDI), untuk memasukkan unsur terms of trade effects; b) Interest Rate Differential (INT), untuk mengukur disparitas antara tingkat pengembalian aset moneter domestik dengan luar negeri.

Data GDI didapatkan melalui pendekatan:

$$
\mathrm{GDI}=\left(\mathrm{d}+\mathrm{x} \frac{P x}{P d}-\mathrm{m} \frac{P m}{P d}\right) * \mathrm{GDP}
$$


Dimana d adalah rasio dari pengeluaran riil domestik terhadap GDP riil. $\mathrm{x}$ adalah bagian eksport di dalam GDP riil, m adalah bagian import di dalam GDP riil, Px adalah indeks harga eksport, Pm adalah indeks harga Import, sedangkan Pd adalah adalah indeks harga barangbarang domestik. Data kuartalan GDP diperoleh melalui data tahunan menggunakan metode dari Aghevli (Aghevli 1977).

Interest Rate Differential (INT) yang mengandung unsur tingkat bunga baik dalam dan luar negeri dan ekspektasi terhadap pergerakan nilai tukar.

$\mathrm{INT}=\mathrm{RF}+\mathrm{E}-\mathrm{RD}$

Dimana RF adalah tingkat bunga luar negeri yang direpresentasikan oleh LIBOR (US\$, 3bulan), E adalah ekspektasi depresiasi rupiah terhadap mata uang lain, dan RD adalah tingkat bunga domestik, yaitu rata-rata suku bunga deposito berjangka 3 bulan.

Ekspektasi tingkat depresiasi direpresentasikan oleh empat alternatif data (semua dalam persentase): 1) perubahan riil dalam nilai tukar efektif dalam kuartal bersangkutan (menggunakan CPI indonesia dan Amerika dalam menghitung purchasing power parity); 2) rata-rata tertimbang dari tingkat perubahan nilai tukar aktual dengan pembobot menggunakan geometrically declining weights; 3) perubahan nilai tukar aktual dalam kuarter bersangkutan; changes in the actual exchange rate in current quarters; dan 4) $\mathrm{E}=0$ merepresentasikan hipotesis tidak adanya ekspektasi nilai tukar. Selain Variabel-variabel diatas digunakan expected rate of domestic inflation (IFL), yang merepresentasikan biaya dalam memegang aset dalam bentuk uang dibandingkan barang-barang. Untuk variabel ini juga terdapat 4 alternatif; 1) rata-rata tertimbang dari tingkat inflasi dengan geometrically declining weights, 2) tingkat inflasi dua kuartal sebelumnya, 3) tingkat inflasi satu kuartal sebelumnya; dan 4) tingkat inflasi pada kuartal yang bersangkutan.

Bobot yang berupa Geometrically declining weights dalam tingkat inflasi didapat dari rata-rata bulanan peningkatan CPI dari setiap kuarter (dalam persentase). Dimasukan pula dalam model ini variabel-variabel-dummy untuk menangkap adanya variasi musim yang tidak dapat dijelaskan oleh variabel-variabel penjelas diatas.

Untuk menentukan ada tidaknya pengaruh daari dua variabel yang menggambarkan keterbukaan ekonomi, dilakukan tes awal untuk setiap komponen uang. Pengujian dilakukan dengan asumsi perekonomian tertutup, yaitu melakukan estimasi dengan menggunakan GDP, IFL, RD dan variabel dummy musiman sebagai variabel penjelas. Kemudian baru dimasukan variabel yang menggambarkan keterbukaan perekonomian satu persatu (menggantin GDP dengan GDI, dan kemudian RD dengan INT) dan melihat apakah ada perbaikan secara statistik. Fungsi dalam bentuk linear dan double-log juga dicoba. Tapi hanya fungsi yang dalam bentuk double-log yang disajikan disini. 
Dari penelitian ini menghasilkan indikasi bahwa beberapa variabel konvensional, seperti tingkat bunga dan inflasi domestik, terbukti mempengaruhi permintaan uang. Untuk kasus Indonesia, setidaknya ada dua variabel yang menggambarkan perekonomian terbuka yang harus diperhitungkan di dalam model. Ditemukan bahwa (GDI), yang mengandung unsur perubahan dari terms of trade dari pendapatan domestik, ternyata menjelaskan model permintaan uang dengan lebih baik dibandingkan variabel konvensional yang biasa digunakan yaitu GDP. Hal ini terutama berlaku bagi komponen Demand Deposit dan uang kuasi. Hal ini menjadi signifikan sejak kemungkinan fluktuasi yang substansial dalam term of trade, dalam tenggang waktu bulanan atau bahkan mingguan, sudah menjadi bagian kehidupan Indonesia sampai beberapa waktu mendatang.

Tingkat bunga luar negeri adalah variabel lainnya yang diperhitungkan untuk menjelaskan perilaku dari permintaan uang. Variabel ini terutama penting untuk menjelaskan pembangunan komponen uang kuasi dalam permintaan uang. Kesimpulan ini menjadi lebih signifikan bila dihubungkan dengan fakta bahwa pertumbuhan uang kuasi meningkat lebih cepat dibandingkan komponen uang yang lainnya, dan tren ini sepertinya akan terus berlanjut dimasa yang akan datang. Variabel lain yang menggambarkan keterbukaan perekonomian yaitu ekspektasi yang berhubungan dengan pergerakan nilai tukar ditemukan tidak signifikan secara statistik. Tapi hal ini mungkin disebabkan oleh sulitnya menemukan pengukuran empiris yang sesuai dibandingkan kekurangannya dalam mempengaruhi permintaan uang.

Penelitian yang dilakukan oleh Price Simon dan Insukendro (1994), mencoba untuk menganalisa komponen permintaan uang dalam arti sempit (money stock) dengan menggunakan teknik ekonometrik modern. Inovasi utama yang dilakukan dalam penelitian ini adalah penggunaan "Forward-looking Model". Pendekatan ini, yang merupakan konsekuensi dari perilaku finansial yang rumit dari sebagian masyarakat Indonesia sebagai agen ekonomi, memiliki implikasi kebijakan yang cukup penting. Salah satunya adalah pengumuman yang dikeluarkan pembuat kebijakan mengenai perubahan dalam kebijakan, bila kredibel, akan mendapat respon dari masyarakat yang lebih besar apabila masyarakat sebagai agen ekonomi tersebut murni berperilaku backward looking. Hal ini dapat menyebabkan operasi yang dilakukan di dalam kebijakan moneter akan lebih efektif.

Secara umum, terdapat kesepakatan mengenai faktor penentu permintaan uang bagi suatu negara dengan perekonomian terbuka seperti Indonesia. Yang membedakan analisa antara perekonomian tertutup dengan perekonomian terbuka adalah kemungkinan alternatif aset yang dapat dipegang oleh pemilik kekayaan, yang lebih dikenal dengan istilah domestic dan foreign Interest Bearing Accounts. Hal ini memiliki implikasi bahwa tingkat bunga simpanan luar negeri akan mempengaruhi permintaan uang. Dengan asumsi log linearity, permintaan uang pada waktu $t, m_{t^{\prime}}$ akan ditentukan oleh: 


$$
m_{t}=a+b y_{t}-c r_{t}-d \hat{r}_{t}
$$

Dengan $b, c$, dan $d>0$, dimana $>0$, dimana $y$ adalah pendapatan, $r$ adalah tingkat bunga domestik, dan $\hat{r}$ adalah tingkat bunga yang dibayarkan dalam memegang mata uang asing.

Dari model tersebut kemudian dapat diturunkan kedalam partial adjusment dan spesifikasi error corection dalam model yang menginkorporasi biaya penyesuaian kuadratik. Model yang dibangun tersebut mengasumsikan agen yang perilakunya forward-looking akan berusaha meminimisasi loss function berikut ini:

$$
L=E \sum_{t=1}^{t=\infty} \rho^{t}\left[\alpha\left(m_{t}-m_{t}^{*}\right)^{2}+\beta\left(m_{t}-m_{t-1}\right)^{2}\right.
$$

Pada persamaan tersebut, $E$ adalah expectation operator (informasi yang tersedia mengenai kondisi pada waktu t), adalah discount rate, $m_{t}$ dan adalah aktual dan optimal stok uang pada waktu t. Loss function tersebut mengasumsikan terdapat dua biaya yang relevan. Biaya yang pertama, (berasosiasi dengan parameter) adalah biaya yang menjauh dari ekuilibrium, keseimbangan statis. Asumsi kuadratik ini akan memastikan biaya tersebut konveks. Biaya yang kedua, (berasosiasi dengan parameter) adalah biaya yang dikeluarkan untuk melakukan penyesuaian dalam mengubah stok uang yang dipegang, biaya ini diasumsikan increasing at the margin. Permasalahannya kini terlihat, dimana kita tidak bisa menurunkan hasilnya secara eksplisit. Dari kodisi turunan pertama (euler), dengan metode Sargent mengenai forward operator, kita dapat menyelesaikan root forward yang tidak stabil untuk menghasilkan persamaan kondisi dibawah ini:

$$
m=\lambda m_{t-1}+(1-\lambda)(1-\lambda \rho) \sum_{s=0}^{s=\infty}(\lambda \rho)^{s} E\left(m_{t+s}^{*}\right)
$$

Pada persamaan tersebut hanya terdapat dua parameter, koefisien pada lag variabel dependent, $\lambda$, dan discount rate. ${ }^{3}$ Besarnya $\lambda$ ditentukan oleh penyesuaian parameter biaya. Semakin besar biaya penyesuaian, semakin besar $\lambda$ dan semakin lambat proses penyesuaian tersebut. Nilai masa depan dari $m^{*}$ tidak dapat diobservasi, oleh karena itu untuk dapat melakukan estimasi perlu dilakukan perhitungan lanjutan.

Model yang dijelaskan diatas menginkorporasi perilaku forward looking yang rumit. Beberapa peneliti berargumen bawa model serupa tidak sesuai untuk digunakan di negara berkembang dimana pasar belum terbangun dengan baik, dan faktor ketidakpastian masih dominan mempengaruhi perekonomian.

3 Pada prakteknya nilai dari discount rate ini ditentukan dalam nilai tertentu di dalam estimasi. 
Selanjutnya akan digunakan mekanisme error-correction sebagai reduced forms dari model forward-looking dan juga sebagai persamaan yang menghasilkan ekspektasi kondisional. Hal ini digambarkan oleh persamaan berikut ini:

$$
m_{t}=\lambda m_{t-1}+\beta\left(L^{-1}\right) m_{t}^{*}
$$

Dan

$m_{t}^{*}=a+b y_{t}$

$\beta\left(\mathrm{L}^{-1}\right)$ adalah polinomial didalam lead-operator dan bagian tingkat bunga pada persamaan diatas dihilangkan. Untuk melengkapi sistem ini, kemudian ditentukan proses stokastik untuk menghasilkan $y$, dengan melakukan dengan merestriksi pada proses vector autoregressive di dalam $y$ dan variabel eksogen $z$.

$y_{t}=\gamma(L) y_{t-1}+\delta(L) z_{t}+\varepsilon_{t}$

Pembentukan ekspektasi kondisional dari informasi yang tersedia pada waktu $t$, dengan aturan berantai dalam peramalan, proyeksi $m_{t+i}^{*}$ akan merupakan fungi linear dari lag $y$ dan $z$. Melalui substitusi, akan didapatkan persamaan dalam bentuk umum:

$$
m_{t}=\lambda m_{t-1}+\Theta(L) y_{t}+\Phi(L) z_{t}
$$

Metode ekonometri yang digunakan meliputi kointegrasi dan mekanisme error-correction dan model forward looking. Model Error-correction yang digunakan disini adalah model yang pertama kali dikenalkan oleh Denis Sargan (1964), dan dipopulerkan oleh Hendry dan para pengikutnya. Selanjutnya Engle dan Granger (1987) selanjutnya menunjukan bila terdapat keseimbangan ataupun hubungan kointegrasi antara variabel yang tidak stasioner, maka representasi Error-correction dari data akan eksis. Engle dan Granger menunjukan bahwa bila terdapat hubungan kointegrasi, maka model regresi sederhana (OLS) regresi statis, mengabaikan aspek dinamis, akan menghasilkan estimasi jangka panjang dan parameter keseimbangan yang super-consistent. Prekondisi dari keberadaan kointegrasi adalah bahwa semua variabel terintegrasi didalam order yang sama. Untuk mengujinya dilakukan uji Dickey-Fuller (DF) dan Augmented Dickey-Fuller (ADF). Beberapa versi dari tes ini juga digunakan untuk menguji keberadaan kointegrasi. Terdapat pula beberapa alternatif untuk menguji kointegrasi ini, diantaranya adalah uji t terhadap error correction term yang mengacu pada uji dari Johansen (1988).

Dalam model forward looking yang pertama dilakukan adalah melakukan estimasi parameter jangka panjang menggunakan teknik kointegrasi. Estimasi ini dapat digunakan bersama data eksogen yang direalisasikan dalam membentuk jalur keseimbangan. Dengan menggunakan nilai yang telah dihasilkan ini, kemudian disubstitusikan kedalam persamaan 
diatas, yang telah diestimasi (secara non linear) oleh beberapa variabel instrumental. Hasilnya digunakan sebagai substitusi dari nilai aktual masa depan untuk ekspektasi. Dalam melakukan hal ini yang perlu diperhatikan adalah harus dilakukan tes yang hati-hati terhadap keberadaan autokorelasi. Metode ini pernah digunakan oleh Callen et all (1990). dan Price (1992), tapi tidak dalam konteks permintaan uang dinegara berkembang.

Dalam penelitian ini ditemukan bahwa uang kartal memiliki elastisitas pendapatan dibawah satu sedangkan demand deposit elastisitas pendapatannya bernilai diatas satu. Ditemukan pula bahwa permintaan uang tersebut juga dipengaruhi oleh tingkat bunga, baik domestik ataupun pengaruh faktor tingkat bunga luar negeri. Penyesuaian ke arah keseimbangan melalui mekanisme perbaikan kesalahan, yang ditunjukan oleh besarnya koefisien error-correction mechanism, menunjukkan nilai yang cukup besar, dimana penyesuaian untuk uang kartal memiliki nilai yang lebih besar dibandingkan demand deposit, seperti yang diharapkan. Dari kajian terlihat pula bahwa masyarakat sebagai agen ekonomi berperilaku rasional, berperilaku forward-looking. Dimana hal ini ditunjukkan bila ada pengumuman kebijakan (bila kebijakan dinilai kredibel), maka perilaku masyarakat akan segera menyesuaikan.

Triatmo Doriyanto (1999), mencoba mengetahui apakah permintaan uang riil di Indonesia selama periode sebelum krisis (sebelum Agustus 1997) dan saat krisis tetap stabil. Studi yang dilakukan mempergunakan observasi bulanan (seasonally unadjusted) 1 selama periode 1988:01 - 1999:03 untuk permintaan uang (CURRENCY) yang dideflasikan terhadap Indeks Harga Konsumen (IHK) dengan tahun dasar 1996. Produk Domestik Bruto Riil (PDBREAL) dipergunakan sebagai variabel untuk menaksir transaksi permintaan uang yang terjadi. Data kwartalan yang akan dipergunakan telah dilakukan "spline" untuk menjadi data bulanan. Tingkat inflasi (INFBUL) dan suku bunga yang dipergunakan adalah suku bunga deposito 1 bulan (DEP1) sebagai penaksir opportunity cost menyimpan currency. Nilai tukar (ER) juga berpengaruh terhadap permintaan uang terutama setelah pemberlakuan sistem nilai tukar berubah menjadi free floating. Selanjutnya dibuktikan bahwa permintaan uang riil di Indonesia tetap stabil sebelum dan selama krisis. Analisis kointegrasi menggunakan teknik Johansen menunjukkan hubungan kointegrasi yang kuat antara currency riil dan PDB riil. Model dinamis permintaan uang riil dengan menggunakan Error Correction Model (ECM) menunjukkan konsistensi parameter yang ditaksir bahkan selama krisis terjadi. Disimpulkan pula bahwa perubahan yang signifikan pada permintaan uang riil karena adanya krisis dapat dijelaskan dengan perubahan pada variabelvariabel yang secara historis memang mempengaruhi permintaan uang di Indonesia. 


\section{MODEL DAN DATA}

Kajian ini dilakukan untuk dapat memproyeksi uang kartal yang sesuai, oleh karena itu dalam kajian ini akan dibatasi pengembangan penggunaan model ARIMA dan model VAR. Adapun Variabel yang digunakan dalam model ARIMA adalah uang kartal dan untuk model VAR yaitu variabel uang kartal, kredit, net foreign asset, reserve, IHSG nilai tukar.

\section{III.1. Model ARIMA}

Dalam penelitian ini model yang dibangun adalah dengan menggunakan pendekatan ARIMA, atas dasar posisi data uang kartal di masyarakat secara bulanan sejak April 1984 hingga Maret 2007. Untuk menguji kemampuan daya prediksi dari model ARIMA yang dibangun, maka akan diperbandingkan output proyeksi dari model dengan data aktual. Pengolahan data akan dilakukan dengan menggunakan software SPSS.

Beberapa langkah pembentukan model ARIMA yang akan dilakukan, yaitu (Nachrowi et al , 2006)

Langkah pertama adalah identifikasi dari model. Indentifikasi dari model meliputi Identifikasi dari kestasioneran data dan indentifikasi dari ordo ARIMA.

Agar data dapat dimodelkan dengan ARIMA, maka hal pertama yang harus diperhatikan adalah data tersebut haruslah stasioner. Jika data stasioner dalam level maka data dapat dimodelkan dengan ARMA. Sedangkan jika data stasioner dalam bentuk difference (1st atau 2nd) maka data dapat dimodelkan dengan ARIMA.

Untuk melakukan pendugaan tentang stasioneritas data, maka kita bisa melakukan 2 cara yaitu secara formal dan informal.

Pendugaan secara informal bisa dilakukan dengan:

1. Melihat trendnya dalam grafik

2. Menggunakan correlogram.

Dengan melihatnya dalam grafik, maka kita bisa melakukan pendugaan awal tentang stasioneritas data. Untuk membuat lebih yakin, maka kita perlu melakukan dengan correlogram. Dengan menggunakan correlogram, maka akan kita cari apakah data stationer dalam level, 1st difference atau 2nd difference. Jika data tidak stasioner dalam level, maka perlu diketahui apakah data sales stasioner dalam 1st difference atau 2nd difference agar dapat dimodelkan dengan ARIMA. 
Data yang stasioner ditandai dengan koefisien autokorelasinya (ACF) setelah time lag 2 atau 3 akan menuju nol. Indentifikasi kesatationeran data diperlukan untuk menentukan apakah data yang dipergunakan dapat dilakukan untuk pengembangan model ARIMA. Bila data telah stationer pada tingkat levelnya, maka pendekatan yang dipergunakan adalah dengan menggunakan pendekatan ARMA, sedangkan apabila data stationer pada level $1^{\text {st }}$ defference atau $2^{\text {nd }}$ defference, maka data dapat dipergunakan untuk permodelan ARIMA. Pada tahap identifikasi akan ditentukan lag AR dan MA yang sesuai dengan bantuan korelogram otokorelasi dan korelogram otokorelasi partial.

Langkah kedua menentukan ordo maksimal $\mathrm{AR}(\mathrm{p})$ dan $\mathrm{MA}(\mathrm{q})$. Untuk menentukan ordo maksimal $A R(p)$ dan ordo maksimal $M A(q)$ dapat dilihat dari banyaknya koefisien autokoreasi yang signifikan berbeda dari nol. Untuk menentukan ordo maksimal $A R(p)$, kita melihat dari garis Partial Autocorrelation. Sedangkan untuk menentukan ordo maksimal MA(q), kita melihat dari garis Autocorrelation.

Langkah ketiga adalah diagnostic checking dan pemilihan model yang terbaik. Setelah model ARIMA ditentukan maka dipilih model yang cocok dengan data. Model yang cocok dengan data diindikasikan dnegan mengamati apakah residual dari model terestimasi merupakan white noise atau tidak

Langkah keempat tahap peramalan

Model ARIMA berdasarkan pada model AR dan model MA.

\section{Model AR(p)}

$\mathrm{Y}_{\mathrm{t}}=\alpha_{\mathrm{o}}+\alpha_{1} \mathrm{Y}_{\mathrm{t}-1}+\alpha_{2} \mathrm{Y}_{\mathrm{t}-2}+\alpha_{3} \mathrm{Y}_{\mathrm{t}-3}+\ldots \ldots+\alpha_{\mathrm{p}} \mathrm{Y}_{\mathrm{t}-\mathrm{p}}+\mathrm{e}_{\mathrm{t}}$

\section{Model MA(q)}

$\mathrm{Y}_{\mathrm{t}}=\beta_{\mathrm{o}}+\mathrm{e}_{\mathrm{t}}-\beta_{1} \mathrm{e}_{\mathrm{t}-1}-\beta_{2} \mathrm{e}_{\mathrm{t}-2}-\beta_{3} \mathrm{e}_{\mathrm{t}-3}-\ldots \ldots \ldots-\beta_{\mathrm{q}} \mathrm{e}_{\mathrm{t}-\mathrm{q}}$

\section{Model ARMA $(p, q)$}

$\mathrm{Y}_{\mathrm{t}}=\gamma_{0}+\alpha_{1} \mathrm{Y}_{\mathrm{t}-1}+\alpha_{2} \mathrm{Y}_{\mathrm{t}-2}+\alpha_{3} \mathrm{Y}_{\mathrm{t}-3}+\ldots .+\alpha_{\mathrm{p}} \mathrm{Y}_{\mathrm{t}-\mathrm{p}}-\beta_{1} \mathrm{e}_{\mathrm{t}-1}-\beta_{2} \mathrm{e}_{\mathrm{t}-2}-\beta_{3} \mathrm{e}_{\mathrm{t}-3}-\ldots-\beta_{\mathrm{q}} \mathrm{e}_{\mathrm{t}-\mathrm{q}}+\mathrm{e}_{\mathrm{t}}$

\section{Misal model ARIMA $(2,1,2)$ dengan ordo differencing $=1$}

$\operatorname{ARMA}(2,2) \quad: \mathrm{Y}_{\mathrm{t}}=\gamma_{0}+\alpha_{1} \mathrm{Y}_{\mathrm{t}-1}+\alpha_{2} \mathrm{Y}_{\mathrm{t}-2}-\beta_{1} \mathrm{e}_{\mathrm{t}-1}-\beta_{2} \mathrm{e}_{\mathrm{t}-2}+\mathrm{e}_{\mathrm{t}}$

$\operatorname{ARIMA}(2,1,2): \mathrm{Y}_{\mathrm{t}}-\mathrm{Y}_{\mathrm{t}-1}=\gamma_{0}+\alpha_{1}\left(\mathrm{Y}_{\mathrm{t}-1}-\mathrm{Y}_{\mathrm{t}-2}\right)+\alpha_{2}\left(\mathrm{Y}_{\mathrm{t}-2}-\mathrm{Y}_{\mathrm{t}-3}\right)-\beta_{1} \mathrm{e}_{\mathrm{t}-1}-\beta_{2} \mathrm{e}_{\mathrm{t}-2}+\mathrm{e}_{\mathrm{t}}$ 


\section{III.2. Model VAR}

Dalam simultaneous-equation regression models ${ }^{4}$ beberapa variabel-variabel diperlakukan sebagai variabel-variabel endogen dan beberapa variabel diperlakukan sebagai variabel eksogen atau predetermined (exogenous plus lagged endogenous). Sebelum diestimasi, dilakukan identifikasi persamaan dalam simultaneous-equation regression models (baik exactly atau over identified) dengan cara mengasumsikan bahwa beberapa variabel-variabel predetermined ada hanya dalam beberapa persamaan. Keputusan-keputusan dalam simultaneous-equation regression models sering kali subyektif dan secara serius dikritik oleh Christopher A. Sims (1980) yang menyatakan bahwa jika terdapat true simultaneity antar sehimpunan variabel-variabel, maka semuanya harus diperlakukan secara simultan; tidak perlu ada pemisahan yang a priori antara variabel-variabel eksogen dan endogen.

Atas dasar itulah maka penelitian ini mencoba melakukan pendekatan model VAR. Melalui pendekatan non-strukturalnya, metode VAR merupakan metode lebih lanjut sebuah sistem persamaan simultan yang bercirikan pada pemanfaatan beberapa variabel ke dalam model secara bersama-sama. Jika dalam persamaan simultan terdapat variabel endogen ${ }^{5}$ dan eksogen ${ }^{6}$, maka dalam VAR setiap variabel dianggap simetris ${ }^{7}$, karena sulit untuk menentukan secara pasti apakah suatu variabel bersifat endogen atau eksogen, $\operatorname{Sims}(1986)^{8}$. Dalam pendekatan VAR masing-masing variabel endogen dijelaskan oleh nilai-nilai waktu tundanya sendiri, atau nilai-nilai masa lalu dan nilai-nilai waktu tunda dari semua variabel-variabel endogen lainnya dalam model; biasanya tidak ada variabel-variabel eksogen dalam model.

Misalkan terdapat model dengan 2 variabel (bivariate), Y dan Z, yang memiliki hubungan kausalitas simultan seperti berikut:

$$
\begin{aligned}
& \mathrm{y}_{\mathrm{t}}=\mathrm{b}_{10}-\mathrm{b}_{12} \mathrm{z}_{\mathrm{t}}+\gamma_{11} \mathrm{y}_{\mathrm{t}-1}+\gamma_{12} \mathrm{z}_{\mathrm{t}-1}+\varepsilon_{\mathrm{yt}} \\
& \mathrm{z}_{\mathrm{t}}=\mathrm{b}_{20}-\mathrm{b}_{21} \mathrm{y}_{\mathrm{t}}+\gamma_{21} \mathrm{y}_{\mathrm{t}-1}+\gamma_{22} \mathrm{z}_{\mathrm{t}-1}+\varepsilon_{\mathrm{zt}}
\end{aligned}
$$

Sistem persamaan diatas dikenal juga sebagai Struktural VAR atau bentuk sistem primitif. Kedua variabel tersebut ( $Y$ dan Z), secara individual dipengaruhi secara langsung oleh variabel

\footnotetext{
4 Model ini populer pada tahun 1960-an dan 1970-an, akan tetapi setelah terbukti tidak mampu memprediksi kejutan harga minyak tahun 1973 dan 1979 dan juga karena Lucas critique popularitasnya mengalami penurunan. Tentang Lucas critique, lihat Robert $\mathrm{E}$ Lucas, "Econometric Policy Evaluation: A Critique," in Carnegie-Rochester Conference Series, The Phillips Curve, North Holland, Amsterdam, 1976, pp. 19-46.

5 Perubahannya dipengaruhi oleh perubahan variabel lain

6 Perubahannya tidak dipengaruhi oleh perubahan variabel lain atau hanya dipengaruhi oleh perubahannya sendiri

7 Setiap variabel saling mempengaruhi perubahan antar variabel baik secara langsung maupun tidak langsung

8 Menurut Sims, dalam VAR tidak terdapat dikotomi variabel eksogen dan endogen. Jika memang terdapat hubungan kausalitas simultan antar variabel yang diamati, maka variabel-variabel tersebut akan diperlakukan sama.
} 
yang lain, dan secara tidak langsung oleh nilai selang dari setiap variabel di dalam sistem. Sistem persamaan tersebut dapat dibentuk ke dalam notasi matriks berikut:

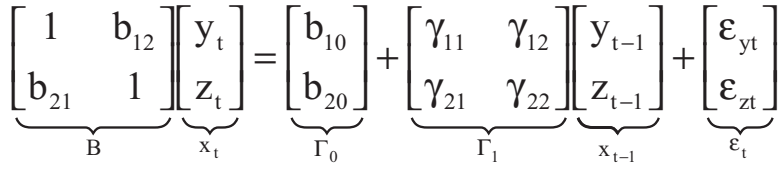

$$
\begin{aligned}
& B \mathrm{x}_{\mathrm{t}}=\Gamma_{0}+\Gamma_{1} \mathrm{x}_{\mathrm{t}-1}+\varepsilon_{\mathrm{t}}
\end{aligned}
$$

Dengan mengalikan inverse B pada notasi matriks persamaan (2) diatas, akan diperoleh:

$$
\mathrm{x}_{\mathrm{t}}=\mathrm{B}^{-1} \Gamma_{0}+\mathrm{B}^{-1} \Gamma_{1} \mathrm{x}_{\mathrm{t}-1}+\mathrm{B}^{-1} \varepsilon_{\mathrm{t}}=\mathrm{A}_{0}+\mathrm{A}_{1} \mathrm{x}_{\mathrm{t}-1}+\mathrm{e}_{\mathrm{t}}
$$

atau dalam bentuk persamaan bivariate:

$$
\begin{aligned}
& \mathrm{y}_{\mathrm{t}}=\mathrm{a}_{10}+\mathrm{a}_{11} \mathrm{y}_{\mathrm{t}-1}+\mathrm{a}_{12} \mathrm{z}_{\mathrm{t}-1}+\mathrm{e}_{1 \mathrm{t}} \\
& \mathrm{z}_{\mathrm{t}}=\mathrm{a}_{20}+\mathrm{a}_{21} \mathrm{y}_{\mathrm{t}-1}+\mathrm{a}_{22} \mathrm{z}_{\mathrm{t}-1}+\mathrm{e}_{2 \mathrm{t}}
\end{aligned}
$$

Spesifikasi model VAR meliputi pemilihan variabel dan banyaknya selang yang digunakan di dalam model. Sesuai dengan metodologi Sims (1980), variabel yang digunakan di dalam persamaan VAR dipilih berdasarkan model ekonomi yang relevan. Teori ekonomi jelas berperan di dalam pemilihan variabel ini, karena itu Bernanke dan Blinder (1992) menyebutnya sebagai pendekatan semi-structural VAR.

Pemilihan selang optimal akan memanfaatkan kriteria informasi yang diperoleh dari Akaike Information Critera (AIC), dan Schwarz Criteria (SC). Akaike Information Critera memberikan penalti atas tambahan variabel (termasuk variabel selang), yang mengurangi derajat kebebasan. Oleh karena itu, lag optimal akan ditemukan pada spesifikasi model yang memberikan nilai AIC paling minimum.

Seperti AIC, SC memberikan penalti atas penambahan variabel, namun dengan tingkat penalti yang lebih berat dari AIC. Seperti pada AIC lag optimal dengan metode ini akan ditemukan pada spesifikasi model yang memberikan nilai SC minimum.

Data yang digunakan merupakan data bulanan mulai bulan Januari 1999 hingga bulan Maret 2007. Namun dalam pembentukan model VAR akan digunakan data hingga bulan Juni 2006. Adapun data pada bulan Juli 2006 hingga Maret 2007 yang tidak dipergunakan dalam pembentukan model akan dipergunakan sebagai data aktual yang akan diperbandingkan dengan hasil proyeksi. Proyeksi dari penggunaan model akan dilakukan untuk periode Juli 2006 hingga Juni 2007. Proyeksi dengan menggunakan model VAR yang dibentuk akan dilakukan dengan dan tanpa menambahkan unsur ADD Factor dari software eviews yang ada. 
Semua data didapat dari sumber data CEIC. Adapun Variabel yang digunakan di dalam model adalah uang kartal, kredit, net foreign asset, reserve, IHSG nilai tukar.

\section{PEMBAHASAN HASIL}

\section{IV.1. Hasil Pengolahan Data}

\section{IV.1.1. Model ARIMA}

Hasil uji stationeritas data

Dari hasil uji stationeritas data dengan menggunakan corelogram menunjukkan bahwa data uang kartal tidal stationer pada data levelnya. Data stationer tejadi pada 1st defferencenya. Hal ini ditandai dengan koefisien autocorelasinya (ACF) setelah time lag 2 dan 3 menuju ke nol (lihat lampiran). Dengan demikian data uang kartal dapat dipakai untuk melakukan pemodelan dengan menggunakan pendekatan ARIMA.

Penentuan Ordo Maksimal AR(p) dan MA(q).

Penentuan ordo maksimal $\mathrm{AR}(\mathrm{p})$ dan $\mathrm{MA}(\mathrm{q})$ dilakukan dengan mengacu pada autocorrelation dan partial correlation atas data pada 1st defference, sebagaimana tampak dibawah

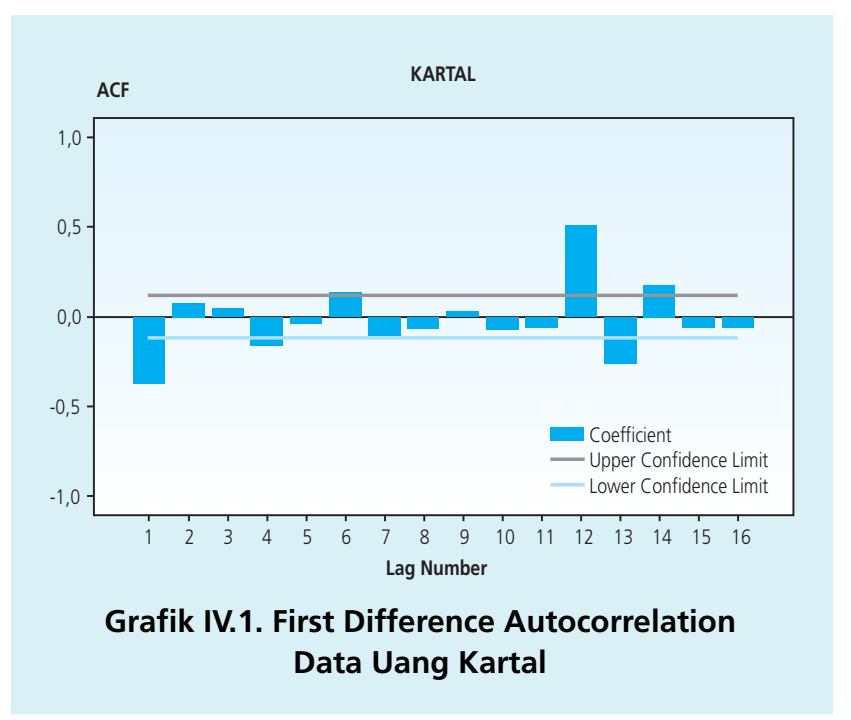




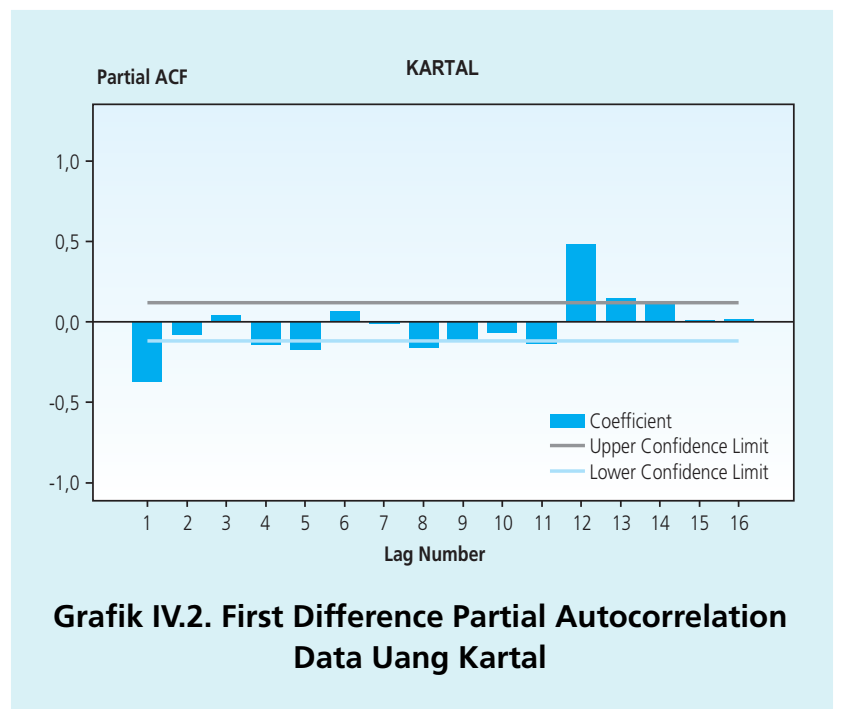

Dengan melihat garis PACF diperoleh ordo $A R(p)$ dan atas dasar garis $A C F$ diperoleh ordo MA(q). Terdapat beberapa kemungkinan model ARIMA yang dapat dibangun, yaitu ARIMA $(12,1,13) \operatorname{ARIMA}(12,1,6) \operatorname{ARIMA}(13,1,5), \operatorname{ARIMA}(13,1,1), \operatorname{ARIMA}(12,1,6)$ dan $\operatorname{ARIMA}(13,1,13)$

\begin{tabular}{|c|c|c|c|c|c|c|}
\hline \multicolumn{7}{|c|}{$\begin{array}{c}\text { Table IV.1. } \\
\text { Pengujian Model ARIMA }(p, d, q)\end{array}$} \\
\hline Model ARIMA & $\begin{array}{l}\text { Paramenter } \\
\text { Yg Significan }\end{array}$ & Estimated & $\rho$-Value & AIC & BIC & $\begin{array}{c}\text { Standar error } \\
\text { of estimasi }\end{array}$ \\
\hline ARIMA $(12,1,13)$ & $\begin{array}{l}\text { AR1 } \\
\text { AR2 } \\
\text { AR3 } \\
\text { AR5 } \\
\text { AR7 } \\
\text { AR11 } \\
\text { AR12 } \\
\text { MA2 } \\
\text { MA5 } \\
\text { MA11 } \\
\text { MA13 } \\
\text { Constant }\end{array}$ & $\begin{array}{r}-, 424 \\
, 135 \\
, 204 \\
-, 236 \\
, 174 \\
, 477 \\
, 743 \\
, 252 \\
-, 203 \\
, 766 \\
-, 335 \\
571,543\end{array}$ & \begin{tabular}{l|}
, 000 \\
, 025 \\
, 002 \\
, 001 \\
, 023 \\
, 000 \\
, 000 \\
, 000 \\
, 028 \\
.025 \\
.025 \\
, 066 \\
.218
\end{tabular} & 5299,443 & 5394,589 & 2265,088 \\
\hline $\operatorname{ARIMA}(12,1,6)$ & $\begin{array}{l}\text { AR1 } \\
\text { AR4 } \\
\text { AR5 } \\
\text { AR12 } \\
\text { MA1 } \\
\text { MA5 } \\
\text { Constant }\end{array}$ & $\begin{array}{r}-, 221 \\
-, 214 \\
-, 201 \\
, 625 \\
, 247 \\
-, 196 \\
473,248\end{array}$ & $\begin{array}{l}.020 \\
.018 \\
.045 \\
, 000 \\
.032 \\
.099 \\
.001\end{array}$ & 5364,056 & 5433,586 & 2638,706 \\
\hline
\end{tabular}




\begin{tabular}{|c|c|c|c|c|c|c|}
\hline \multicolumn{7}{|c|}{$\begin{array}{c}\text { Table IV.1 } \\
\text { Pengujian Model ARIMA (p,d,q) (lanjutan) }\end{array}$} \\
\hline Model ARIMA & $\begin{array}{l}\text { Paramenter } \\
\text { Yg Significan }\end{array}$ & Estimated & $\rho$-Value & AIC & BIC & $\begin{array}{c}\text { Standar error } \\
\text { of estimasi }\end{array}$ \\
\hline ARIMA $(13,1,5)$ & $\begin{array}{l}\text { AR1 } \\
\text { AR2 } \\
\text { AR4 } \\
\text { AR6 } \\
\text { AR11 } \\
\text { AR12 } \\
\text { AR13 } \\
\text { MA1 } \\
\text { Constant }\end{array}$ & $\begin{array}{r}, 703 \\
, 365 \\
-, 223 \\
, 168 \\
, 125 \\
, 544 \\
-, 540 \\
1,185 \\
542,546\end{array}$ & $\begin{array}{l}.000 \\
, 001 \\
.076 \\
.042 \\
.099 \\
.000 \\
.000 \\
.000 \\
.153\end{array}$ & 5364,390 & 5433,920 & 2641,976 \\
\hline $\operatorname{ARIMA}(13,1,1)$ & $\begin{array}{l}\text { AR2 } \\
\text { AR4 } \\
\text { AR11 } \\
\text { AR12 } \\
\text { MA1 } \\
\text { Constant }\end{array}$ & $\begin{array}{r}, 191 \\
-, 161 \\
, 130 \\
, 615 \\
, 618 \\
480,609\end{array}$ & $\begin{array}{l}, 030 \\
, 003 \\
, 025 \\
, 000 \\
, 002 \\
, 015\end{array}$ & 5362,236 & 5417,128 & 2653,429 \\
\hline ARIMA $(12,1,6)$ & $\begin{array}{l}\text { AR1 } \\
\text { AR4 } \\
\text { AR5 } \\
\text { AR12 } \\
\text { MA1 } \\
\text { MA5 } \\
\text { Constant }\end{array}$ & $\begin{array}{r}-, 221 \\
-, 214 \\
-, 201 \\
, 625 \\
, 247 \\
-, 196 \\
473,248\end{array}$ & $\begin{array}{l}, 020 \\
.018 \\
, 045 \\
, 000 \\
, 032 \\
.099 \\
.001\end{array}$ & 5364,056 & 5433,586 & 2638,706 \\
\hline $\operatorname{ARIMA}(13,1,13)$ & $\begin{array}{l}\text { AR1 } \\
\text { AR3 } \\
\text { AR5 } \\
\text { AR11 } \\
\text { AR12 } \\
\text { AR13 } \\
\text { MA1 } \\
\text { MA2 } \\
\text { MA3 } \\
\text { MA11 } \\
\text { MA12 } \\
\text { MA13 } \\
\text { Constant }\end{array}$ & $\begin{array}{r}-1,122 \\
, 215 \\
-, 240 \\
, 309 \\
1,042 \\
, 670 \\
-, 717 \\
, 389 \\
, 207 \\
, 532 \\
, 287 \\
-, 243 \\
554,575\end{array}$ & $\begin{array}{l}, 000 \\
.017 \\
, 009 \\
, 002 \\
, 000 \\
, 000 \\
, 000 \\
, 001 \\
, 081 \\
.000 \\
, 000 \\
, 058 \\
.044 \\
.202\end{array}$ & 5314,590 & 5413,396 & 2350,446 \\
\hline
\end{tabular}

Dengan memperhatikan Akaike's Information Criterion (AIC), Schwarz's Bayesian Criterion $(B I C)$ dan standar error residual yang terkecil maka ARIMA $(12,1,13)$ merupakan model yang paling sesuai. Hal ini didukung dengan uji white noise dengan menggunakan pendekatan correlogram atas error term dari model dimaksud yang menunjukkan kondisi white noise (lihat lampiran). 
Dengan demikian didapat model sebagai berikut :

$$
\begin{aligned}
y_{t}-y_{t-1}= & 571,543-0,424\left(y_{t-1}-y_{t-2}\right)+0,135\left(y_{t-2}-y_{t-3}\right)+0,204\left(y_{t-3}-y_{t-4}\right)-0,236\left(y_{t-5}-y_{t-6}\right)+0,174\left(y_{t-7}-\right. \\
& \left.y_{t-8}\right)+0,477\left(y_{t-11}-y_{t-12}\right)+0,743\left(y_{t-12}-y_{t-13}\right)-0,252 e_{2}+0,203 e_{5}-0,766 e_{11}+0,335 e_{13} \\
y_{t}= & 571,543+y_{t-1}-0,424\left(y_{t-1}-y_{t-2}\right)+0,135\left(y_{t-2}-y_{t-3}\right)+0,204\left(y_{t-3}-y_{t-4}\right)-0,236\left(y_{t-5}-y_{t-6}\right)+0,174 \\
& \left(y_{t-7}-y_{t-8}\right)+0,477\left(y_{t-11}-y_{t-12}\right)+0,743\left(y_{t-12}-y_{t-13}\right)-0,252 e_{2}+0,203 e_{5}-0,766 e_{11}+0,335 e_{13}
\end{aligned}
$$

Adapun hasil proyeksi uang kartal adalah sebagai berikut:

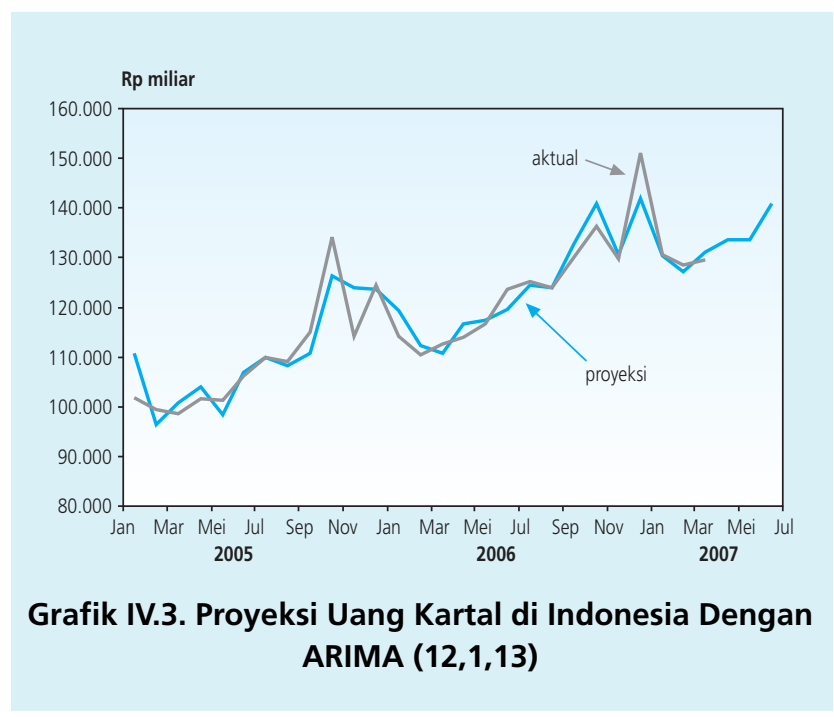

Tabel IV.2.

Perbandingan Aktual dan Proyeksi

Uang Kartal Dengan Pendekatan ARIMA $(12,1,13)$ di Indonesia

\begin{tabular}{l|c|c} 
& AKTUAL & PROYEKSI \\
Jan-06 & 114.318 & 119.433 \\
Feb-06 & 110.567 & 112.320 \\
Mar-06 & 112.625 & 110.710 \\
Apr-06 & 113.935 & 116.762 \\
Mei-06 & 116.569 & 117.542 \\
Jun-06 & 123.761 & 119.562 \\
Jul-06 & 125.219 & 124.509 \\
Agust-06 & 123.777 & 123.873 \\
Sep-06 & 129.969 & 132.770 \\
Okt-06 & 136.259 & 140.947 \\
Nop-06 & 129.702 & 130.545 \\
Des-06 & 151.009 & 142.080 \\
Jan-07 & 130.666 & 130.374
\end{tabular}




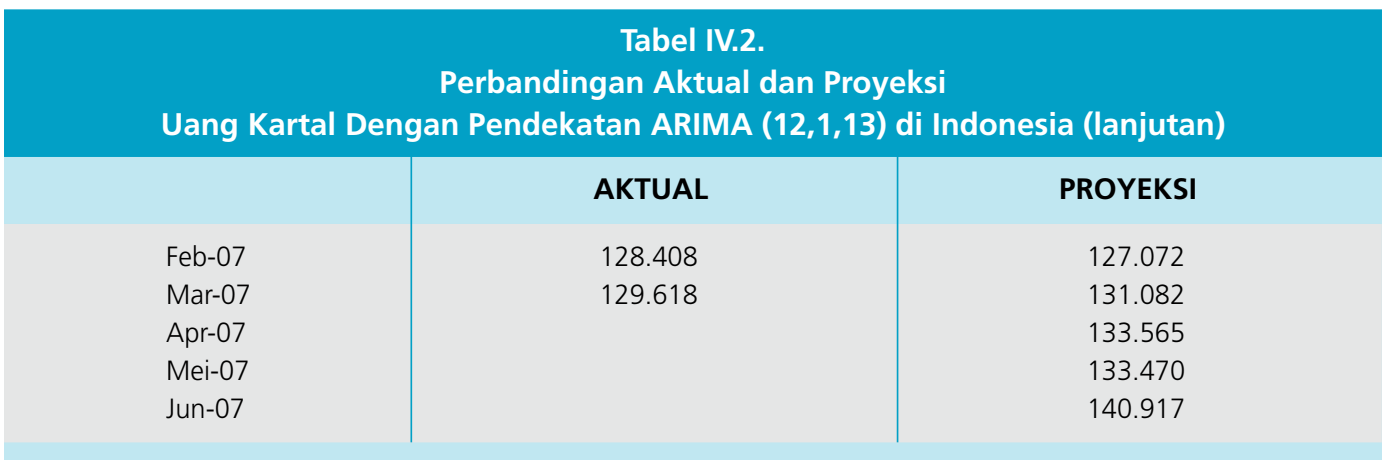

Rata-rata deviasi proyeksi dengan data aktual sebesar 2,6\%.

\section{IV.1.2. Model VAR}

Seperti yang telah dipaparkan diatas, pengujian empiris yang dilakukan pada penelitian ini diantaranya menggunakan metode VAR. Metode VAR ini dipilih berkaitan dengan tujuan utama dilakukannya penelitian ini adalah untuk memproyeksikan uang kartal di masyarakat untuk beberapa periode kedepan.

Variabel yang digunakan adalah uang kartal (currency), net foreign asset (NFA), kredit perbankan (kredit), nilai tukar (ER), indeks harga saham gabungan (IHSG), dan cadangan devisa (reserve). Variabel-variabel tersebut sebelum diestimasi menggunakan sistem VAR terlebih dahulu diuji kestasioneran datanya menggunakan uji Augmented Dickey Fuller (ADF) dan Phillips-Perron $(P P)$. dari hasil uji tersebut akan didapatkan nilai kritis dari masing-masing metode tersebut.

\begin{tabular}{|c|c|c|c|c|}
\hline \multirow{3}{*}{ Variabel } & \multicolumn{3}{|c|}{$\begin{array}{c}\text { Tabel IV.3. } \\
\text { Hasil Uji Stasioneritas }\end{array}$} & \\
\hline & \multicolumn{2}{|c|}{ ADF } & \multicolumn{2}{|c|}{ PP } \\
\hline & $I(0)$ & I (1) & $I(0)$ & I (1) \\
\hline Currency & 1.0000 & 0.0090 & 0.9197 & 0.0001 \\
\hline NFA & 0.6980 & 0.0000 & 0.8105 & 0.0000 \\
\hline Kredit & 0.9959 & 0.0000 & 0.9698 & 0.0000 \\
\hline ER & 0.1555 & 0.0000 & 0.1654 & 0.0000 \\
\hline IHSG & 0.9877 & 0.0000 & 0.9855 & 0.0000 \\
\hline Reserve & 0.4136 & 0.0000 & 0.7133 & 0.0001 \\
\hline
\end{tabular}

Baik melalui pengujian ADF maupun PP, memperlihatkan bahwa semua variebel stationer pada derajat satu (1). 
Pemilihan panjang selang yang tepat sangatlah krusial bagi sebuah sistem VAR. Jika selang terlalu pendek, model dapat terspesifikasi dengan kurang tepat (mis-spesifikasi), sementara selang yang terlalu panjang akan mengakibatkan banyak derajat kebebasan terbuang. Guna memperoleh panjang selang yang tepat akan dilihat panjang selang maksimum sistem VAR yang stabil. Stabilitas sistem VAR dapat dilihat dari nilai inverse roots karakteristik AR polinomialnya. Suatu sistem VAR dikatakan stabil (stasioner) jika seluruh roots-nya memiliki modulus lebih kecil dari satu dan semuanya terletak di dalam unit circle, Lutkepohl (1991). Dari hasil model yang terbentuk menunjukkan model VAR yang dibentuk stabil.

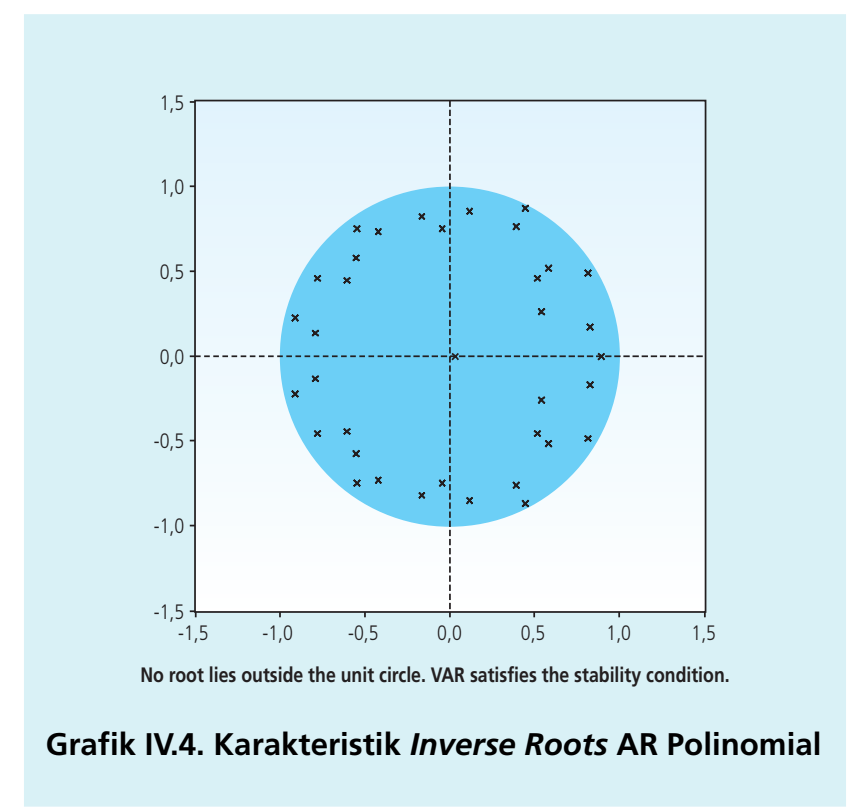

Pada tahap selanjutnya, panjang selang optimal akan dicari dengan menggunakan kriteria informasi yang tersedia. Kandidat selang yang terpilih adalah panjang selang menurut kriteria Likelihood Ratio (LR), Final Prediction Error (FPE), Akaike Information Critrion (AIC), Schwarz Information Criterion (SC), dan Hannan-Quin Criterion (HQ). Jika kriteria informasi hanya merujuk pada sebuah kandidat selang saja, maka kandidat tersebutlah yang optimal. Jika diperoleh lebih dari satu kandidat, maka pemilihan dilanjutkan pada tahap ketiga.

Pada tahap terakhir ini, nilai Adjusted $\mathrm{R}^{2}$ variabel VAR dari masing-masing kandidat selang akan diperbandingkan, dengan penekanan pada variabel-variabel terpenting ${ }^{9}$ dari sistem VAR tersebut. Selang optimal adalah selang tertentu dari sistem VAR yang akan menghasilkan nilai

9 Variabel yang menjadi fokus dalam analisa atau penelitian. 
Adjusted $\mathrm{R}^{2}$ terbesar pada variabel-variabel penting di dalam sistem. Adjusted $\mathrm{R}^{2}$ digunakan karena ia memiliki kemampuan di dalam menjelaskan varians dari variabel dependen ${ }^{10}$. Karenanya nilai Adjusted $\mathrm{R}^{2}$ yang lebih besar akan mencerminkan kemampuan sebuah sistem persamaan yang lebih baik di dalam menjelaskan perilaku variabel dependennya.

Pemilihan panjang selang optimal dengan menggunakan kombinasi tabel AR-roots, kriteria informasi, dan Adjusted $\mathrm{R}^{2}$ secara bertahap. Pada setiap sistem persamaan diatas dihasilkan selang optimal sepanjang 1 periode.

Dalam penelitian ini model yang dihasilkan adalah:

VAR Model:

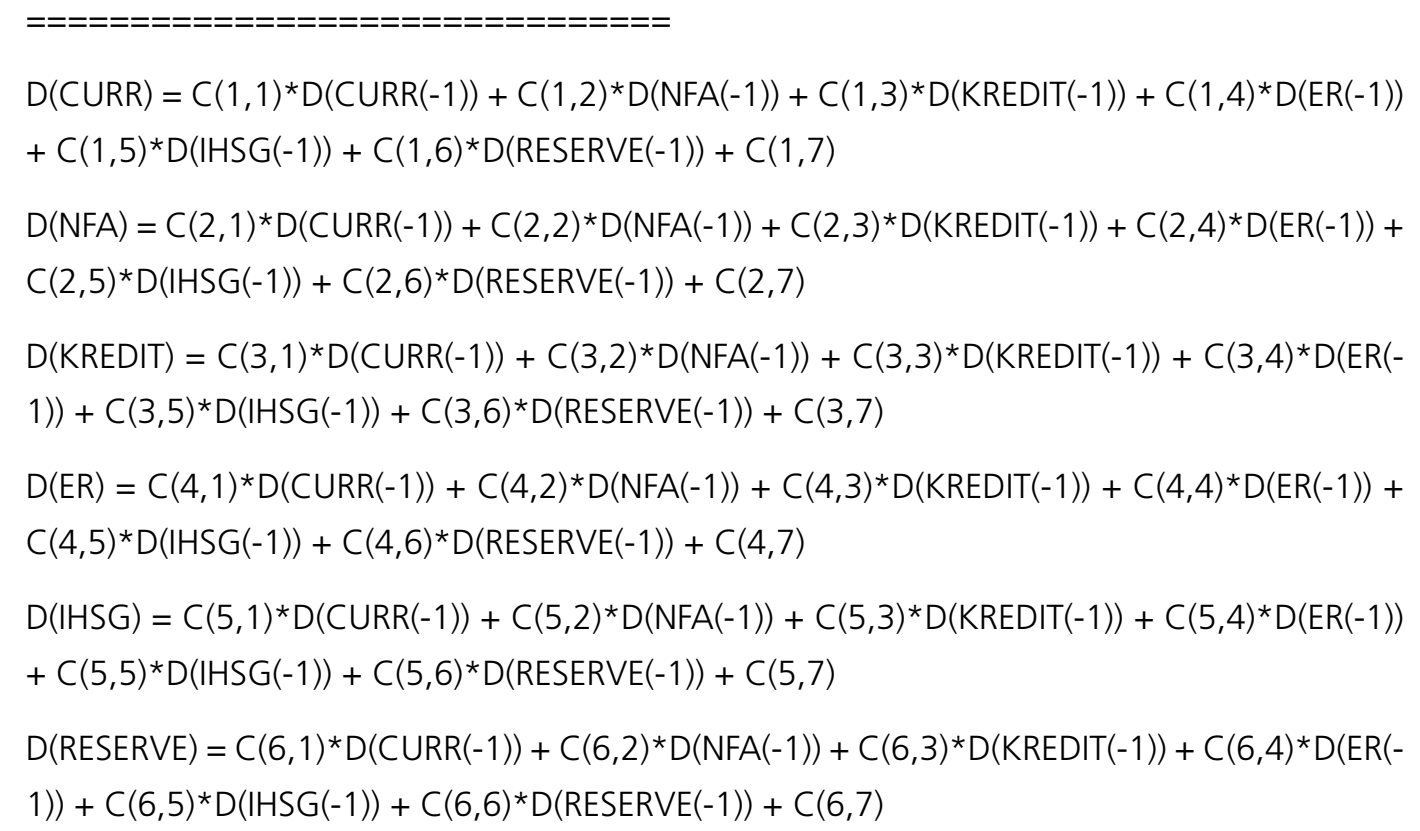

VAR Model - Substituted Coefficients:

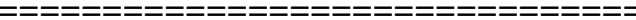

$\mathrm{D}(\mathrm{CURR})=-0.3821778829 * \mathrm{D}(\mathrm{CURR}(-1))+0.1375915597 * \mathrm{D}(\mathrm{NFA}(-1))+$ $0.1557154974 * D(K R E D I T(-1))-5.283650322 * D(E R(-1))-4.895276083 * D(I H S G(-1))-$ $2.148985278 * D(\operatorname{RESERVE}(-1))+756.7641812$

10 Baik yang dapat dijelaskan maupun yang tidak dapat dijelaskan oleh model. 
$\mathrm{D}(\mathrm{NFA})=-0.1032903401 * \mathrm{D}(\mathrm{CURR}(-1))-0.4028372669 * \mathrm{D}(\mathrm{NFA}(-1))+$ $0.03126065816 * \mathrm{D}($ KREDIT $(-1))+15.70339978 * \mathrm{D}(\mathrm{ER}(-1))+40.56145955 * \mathrm{D}(\mathrm{IHSG}(-1))+$ $2.313845161 * D(\operatorname{RESERVE}(-1))+2326.673901$

$\mathrm{D}($ KREDIT $)=-0.2199396574 * \mathrm{D}(\mathrm{CURR}(-1))+0.09301910267 * \mathrm{D}(\mathrm{NFA}(-1))+$ $0.3811374641 * D(K R E D I T(-1))-10.80212786 * D(E R(-1))-9.704301539 * D(I H S G(-1))-$ $2.475914261 * D(R E S E R V E(-1))+4346.042924$

$D(E R)=-0.003688509573 * D(C U R R(-1))-0.009234242188 * D(N F A(-1))+$ $0.0005556008632 * \mathrm{D}($ KREDIT $(-1))+0.2393288702 * \mathrm{D}(\mathrm{ER}(-1))-0.9422175797{ }^{*} \mathrm{D}(\mathrm{IHSG}(-1))+$ $0.03307424521 * D(\operatorname{RESERVE}(-1))+43.45541674$

$\mathrm{D}(\mathrm{IHSG})=0.000293119652 * \mathrm{D}(\mathrm{CURR}(-1))+0.0007219942834 * \mathrm{D}(\mathrm{NFA}(-1))+$ $0.001214687218 * D($ KREDIT(-1)) $-0.03094980556 * D(E R(-1))+0.04644454491 * D(I H S G(-1))$ $+0.003023430698 * \mathrm{D}(\operatorname{RESERVE}(-1))-0.4100095525$

$D($ RESERVE $)=-0.0002359074415 * D(C U R R(-1))-0.004052222581 * D(N F A(-1))-$ $0.01029424106 * \mathrm{D}($ KREDIT(-1)) $+0.1061049918 * \mathrm{D}(\mathrm{ER}(-1))+5.029347914 * \mathrm{D}(\mathrm{IHSG}(-1))+$ $0.2525864114 * D(\operatorname{RESERVE}(-1))+159.2158638$

Dari model yang dibentuk dilakukan tahap proyeksi untuk periode antara Juli 2006 hingga Juni 2007. Dalam proyeksi dengan menggunakan pendekatan VAR ini akan dilakukan dengan dua tahap, yaitu proyeksi yang hanya mendasarkan pada model yang ada dan proyeksi dengan memasukkan unsur ADD factor dalam Eviews dengan maksud untuk pemulusan atas hasil proyeksi. Adapun hasil proyeksi adalah sebagai berikut:

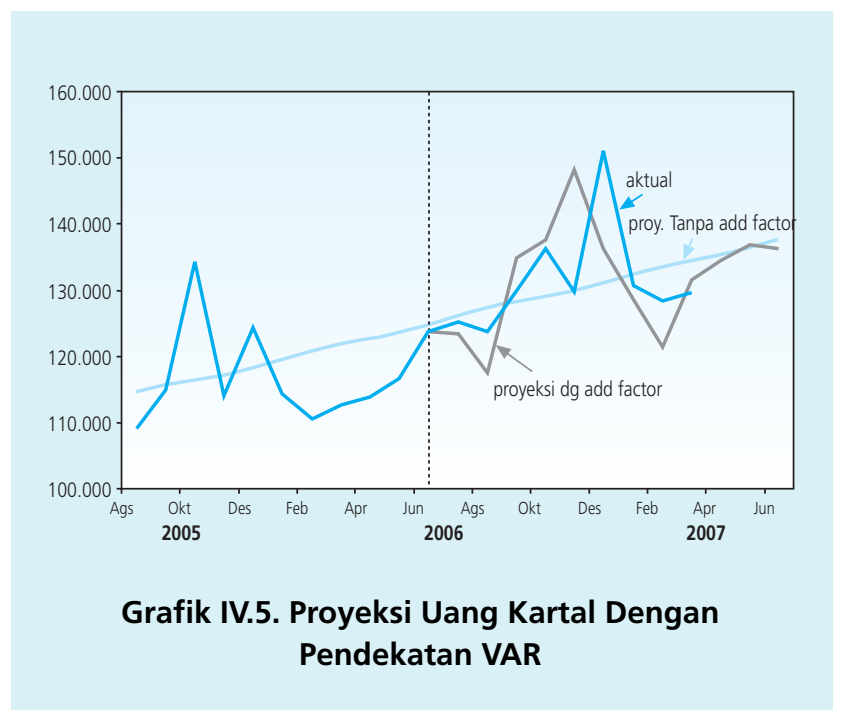




\begin{tabular}{|c|c|c|c|}
\hline \multicolumn{4}{|c|}{$\begin{array}{c}\text { Tabel IV.4. } \\
\text { Proyeksi Uang Kartal Masyarakat Dengan Menggunakan VAR } \\
\text { ( dalam Milyar Rupiah ) }\end{array}$} \\
\hline & Aktual & Proyeksi Var & $\begin{array}{c}\text { Proyeksi DG ADD } \\
\text { Factor }\end{array}$ \\
\hline Jan-06 & 114.318 & 119.574 & 114.318 \\
\hline Feb-06 & 110.567 & 120.894 & 110.567 \\
\hline Mar-06 & 112.625 & 121.863 & 112.625 \\
\hline Apr-06 & 113.935 & 122.653 & 113.935 \\
\hline Mei-06 & 116.569 & 123.588 & 116.569 \\
\hline Jun-06 & 123.761 & 124.781 & 123.761 \\
\hline Jul-06 & 125.219 & 126.114 & 123.435 \\
\hline Agust-06 & 123.777 & 127.303 & 117.483 \\
\hline Sep-06 & 129.969 & 128.215 & 134.953 \\
\hline Okt-06 & 136.259 & 128.989 & 137.633 \\
\hline Nop-06 & 129.702 & 129.985 & 148.260 \\
\hline Des-06 & 151.009 & 131.170 & 136.286 \\
\hline Jan-07 & 130.666 & 132.464 & 128.591 \\
\hline Feb-07 & 128.408 & 133.567 & 121.534 \\
\hline Mar-07 & 129.618 & 134.462 & 131.562 \\
\hline Apr-07 & & 135.332 & 134.473 \\
\hline Mei-07 & & 136.407 & 136.932 \\
\hline Jun-07 & & 137.648 & 136.309 \\
\hline
\end{tabular}

Rata-rata deviasi dengan model VAR sebesar 5,2\%, sedangkan dengan menggunakan model VAR dan ADD factor maka rata-rata deviasinya sebesar $6,5 \%$.

\section{IV.2. Pembahasan Hasil}

Pendekatan ARIMA $(12,1,13)$ dapat menghasilkan proyeksi uang kartal untuk jangka waktu hingga 12 periode kedepan (12 bulan) dengan rata-rata deviasi sebesar 2.6\%. Hal ini lebih baik dibanding proyeksi uang kartal dengan pendekatan model VAR yang menghasilkan deviasi 5,2\% untuk model VAR tanpa ADD Factor dan 6,5\% untuk model VAR dengan ADD factor.

Meskipun untuk mendapatkan ordo yang tepat bagi $\operatorname{ARIMA}(p, d, q)$ membutuhkan unsur "coba-coba" dengan mendasarkan pada ACF dan PACF atas data yang telah distabilkan, dalam kasus ini data stabil pada 1st defference, model $\operatorname{ARIMA}(12,1,13)$ dapat membantu dalam melakukan proyeksi posisi uang kartal di masyarakat hingga periode yang cukup panjang dengan tingkat deviasi yang relatif kecil. Sehingga model ini sesuai untuk kondisi dimana penelitian diperhadapkan pada keterbatasan data. Dengan hasil yang ditunjukkan tersebut dapat 
mengindikasikan pula bahwa MA(13) dalam model $\operatorname{ARIMA}(12,1,13)$ mampu menjawab permasalahan gejolak kebutuhan masyarakat akan uang kartal yang berfluktuasi yang mengandung unsur seasonal.

Model VAR yang dihasilkan untuk proyeksi uang kartal adalah mendasarkan pada variabel uang kartal (currency), net foreign asset (NFA), kredit perbankan (kredit), nalai tukar (ER), indeks harga saham gabungan (IHSG), dan cadangan devisa (reserve). Hasil dari model ini memberikan deviasi proyeksi 5,2\% untuk VAR tanpa ADD factor dan 6,5\% untuk model VAR dengan ADD factor. Untuk dapat menekan deviasi tersebut tidak tertutup kemungkinan menggunakan variabel lain seperti produk domestik bruto, pengeluaran pemerintah, konsumsi masyarakat dan data lainnya yang saat ini masih tersedia dalam bentuk data triwulanan. Permasalahannya adalah data triwulanan tersebut harus di konversikan kedalam bentuk data bulanan, jika ingin mempertahankan kajian model VAR dengan basis data bulanan.

\section{KESIMPULAN DAN SARAN}

\section{V.1. Kesimpulan}

Model ARIMA $(12,1,13)$ merupakan model ARIMA yang sesuai guna membantu dalam melakukan proyeksi uang kartal di masyarakat. Model ini berhasil memberikan hasil proyeksi uang kartal dengan tingkat deviasi sebesar 2,6\%. Tingkat ketepatan dalam melakukan proyeksi dari ARIMA $(12,1,13)$ tersebut untuk proyeksi hingga 12 periode kedepan lebih baik dibandingkan dengan pendekatan model VAR tanpa ADD factor dengan deviasi proyeksi 5,2\% maupun model VAR dengan ADD factor dengan deviasi sebesar $6,5 \%$. Model VAR yang dihasilkan untuk proyeksi uang kartal adalah mendasarkan pada variabel uang kartal (currency), net foreign asset (NFA), kredit perbankan (kredit), nilai tukar (ER), indeks harga saham gabungan (IHSG), dan cadangan devisa (reserve).

Model $\operatorname{ARIMA}(12,1,13)$ dapat menjawab permasalahan keterbatasan ketersediaan data lainnya dalam kegiatan proyeksi. Hal ini terlihat dari deviasi yang dihasilkan relatif rendah

\section{V.2. Saran}

Model ARIMA $(12,1,13)$ cukup efekif dipergunakan oleh pihak otoritas moneter dalam melakukan proyeksi posisi uang kartal di masyarakat. Namun karena uang kartal bersifat borderless antar wilayah dalam satu negara, maka pendekatan ini tidak dapat dipergunakan untuk memproyeksikan posisi uang kartal di suatu wilayah tertentu dalam suatu negara (Indonesia) 
Keterbatasan pendekatan ARIMA adalah dalam mendapatkan model ARIMA(p,d, $q)$ yang tepat yang dilakukan dengan cara "coba-coba" dengan mengacu pada autocorrelation dan partial autocorrelation dari data yang telah stationer. Untuk memperoleh model yang tepat membutuhkan waktu, khususnya bila lag bagi AR dan MA cukup panjang dan bervariasi. Untuk itu perlu suatu kajian lebih lanjut untuk menyempurnakan penggunaan ARIMA dalam pembentukan model proyeksi. 


\section{DAFTAR PUSTAKA}

Aghevli B Bijan, (1976), A Model of Monetary Sector for Indonesia, 1968 - 1973, Buletin of Indonesian Economic Studies, Vol. 12, No. 3, November 1976. pp. 50 - 60

Aghevli, B Bijan .(1977), "Money, Prices and the Balance of Payments: Indonesia, 1968 - 1973", Journal of Developmenl Sludies 13, January 1977.

Baumol W. J , (1965), Economic Theory and Operation Analysis, $2^{\text {nd }}$ ed (1965),

Baumol W. J, (1952), The Transaction Demand for Cash - an Inventory Theoritic Approach, Quarterly Journal of Economics, November 1952, hal. 545 - 556.

Boediono, (1985), Demand For Money In Indonesia, 1975 - 1984, Bulletin of Indonesian Economic Studies, Vol. XXI. No. 2, August 1985

Callen, T.S. Hall S.G. and Henry, S.G.B. (1990), "Manufacturing Stock: Expectation, Risk, and Cointegration" Economic Journal 100, 756-74.

Doriyanto Triatmo, 1999, Stabilkah Permintaan Uang di Indonesia Sebelum dan Selama Krisis? , Buletin Ekonomi Moneter dan Perbankan, September 1999

Engle, R.F. and Granger, C.W. (1987). "Cointegration and Error Correction: representation, estimation and testing", Econometrica 55, 251-76.

Fatul, Lucky, (2000), Strategi Operasional Distribusi Uang Kartal yang Efisien dan Efektif di Indonesia, SESPIBI, Bank Indonesia, 2000

Friedman Milton, (1955), The Quantity Theory of Money, a Restatement, dalam Milton Friedman (ed), Studies in the Quantity Theory of Money, Cichago University Press, Chicago (1955).

Johansen, S. (1988) "Statistical Analysis of Cointegrating Vectors". Journal of Economic Dynamic and Control 12, 231-54.

Keynes J. M., (1936), The General Theory of Employment, Interest and Money, Harcourt, Brace \& World, London and New York, 1936

Nachrowi D Nachrowi, Usman Hardius, 2006, Pendekatan Populer dan Praktis Ekonometrika untuk Analisis Ekonomi dan Keuangan. Lembaga Penerbit FE UI, 
Price, S. (1992) "Forward Looking price seting in UK Manufacturing". Economic Journal 102, 497-505.

Sargan Denis, (1964), "Wages and Prices in the United Kingdom: A Studyin Econometric Methodology". In Hart, P.E. Mills, G. and Whitaker, J.K. (eds), Econometrics Analysis for National Economic Planing. London: Butterworths.

Sigalingging, Hotbin, (2004), Kebijakan Pengedaran Uang di Indonesia, Buku Seri Kebanksentralan No 4, PPSK, Bank Indonesia, Juli 2004

Simon Price and Insukendro, (1994), The Demand For Indonesian Narrow Money: Long-run Equilibrium, Error Correction and Forward-looking Behaviour The Journal of International Trade \& Economic Development, 3(2) July 1994, hal 148-163.

Sims A Christopher, (1980), "Macroeconomics and Reality," Econometrica, vol. 48, 1980, pp. $1-48$.

Tobin James, (1956), The Interest Elasticity of Transactions Demand for Cash, Review of Economics and Statistics, August 1956, hal. $241-247$.

Untoro, 2005, Proyeksi Permintaan Uang Kartal di Indonesia : Dengan Pendekatan VAR, Pusat Pendidikan dan Studi Kebanksentralan, Bank Indonesia.

Warjiyo Perry dan Solikin, (2004), Bank Indonesia Bank Sentral Republik Indonesia (Sebuah Pengantar), Pusat Pendidikan dan Studi Kebanksentralan, Bank Indonesia. 
